\title{
Petrography and geochemistry of the Proterozoic sandstones of Somanpalli Group from Pomburna area, Eastern Belt of Pranhita-Godavari Valley, central India: Implications for provenance, weathering and tectonic setting
}

\author{
N K RaO ${ }^{1, *}, \mathrm{M}$ L Dora ${ }^{1}, \mathrm{~S}$ R Baswani ${ }^{1}$, D B Malpe ${ }^{2}$ and M S DeshmukH ${ }^{2}$ \\ ${ }^{1}$ Geological Survey of India, Central Region, Nagpur 440 006, India. \\ 2 Department of Geology, RTM Nagpur University, Nagpur 440 001, India. \\ ${ }^{*}$ Corresponding author. e-mail: nkraogsi@gmail.com
}

MS received 27 September 2017; revised 15 January 2018; accepted 25 January 2018; published online 4 August 2018

In this paper, we, for the first time, report geochemistry of sandstone from Somanpalli Group from Pomburna area in the Eastern Belt of Pranhita-Godavari (PG) Valley, central India and studied to infer their provenance, intensity of paleo-weathering and depositional tectonic setting. Petrographic study of sandstones show QFL modal composition of arenite. Chemical results show high $\mathrm{SiO}_{2}$ and CIA but lower $\mathrm{Al}_{2} \mathrm{O}_{3}, \mathrm{TiO}_{2}, \mathrm{Rb}, \mathrm{Sr}, \mathrm{K}_{2} \mathrm{O}$ indicating mixed sources. Major elements chemistry parameters such as, $\mathrm{K}_{2} \mathrm{O} / \mathrm{Al}_{2} \mathrm{O}_{3}$ ratio and positive correlation of $\mathrm{Rb}$ with $\mathrm{K}_{2} \mathrm{O}$, reflects a warm and humid climate for study area. The tectonic discrimination plots $\left(\mathrm{SiO}_{2} / 20-\mathrm{K}_{2} \mathrm{O}+\mathrm{Na}_{2} \mathrm{O}-\mathrm{TiO}_{2}+\mathrm{Fe}_{2} \mathrm{O}_{3}+\mathrm{MgO} ; \mathrm{K}_{2} \mathrm{O} / \mathrm{Na}_{2} \mathrm{O}\right.$ vs. $\mathrm{SiO}_{2}$; $\mathrm{Th}-\mathrm{Sc}-\mathrm{Zr} / 20)$ indicate dominantly passive margin and slight active tectonic setting. Concentrations of $\mathrm{Zr}, \mathrm{Nb}, \mathrm{Y}$, and Th are higher compared to the UCC values and the trends in $\mathrm{Th} / \mathrm{Cr}, \mathrm{Th} / \mathrm{Co}, \mathrm{La} / \mathrm{Sc}$ and $\mathrm{Cr} / \mathrm{Zr}$ ratios support a felsic and mafic source for these sandstones and deposition in passive margin basin. Chondrite normalized REE pattern reflects LREE depletion, negative Eu anomaly and flat HREE similar to UCC, felsic components. ICV value (0.95) also supports tectonically quiescent passive margin settings. CIA values (74) indicate high degree of chemical weathering and warm and humid paleoclimatic condition.

Keywords. Sandstone; geochemistry; tectonics; provenance; PG Valley.

\section{Introduction}

Sedimentary rocks contain wealth of information about the composition, tectonic setting, and evolutionary growth of the early continental crusts (Taylor and McLennan 1985; McLennan et al. 1993). The original composition of weathered source rocks has a dominant control on the makeup of terrigenous sediments, and therefore, geographic and stratigraphic variations in provenance can provide important constraints on the tectonic evolution of the region (e.g., Clift et al. 2000; McLennan et al. 2003; Rahman and Suzuki 2007; Absar et al. 2009; Absar and Sreenivas 2015; Nagarajan et al. 2017; Tawfik et al. 2017; Zaid 2017). The geochemistry of clastic sedimentary rocks is widely studied to the tectonic setting, weathering, source rock compositions, provenance and 
diagenesis (Dickinson and Suczek 1979; Nesbitt and Young 1982; Bhatia 1983; Roser and Korsch 1986; McLennan 1989; Condie 1993; ArmstrongAltrin et al. 2004; Absar et al. 2009; Moosavirad et al. 2011; Saeed et al. 2011; Randive 2012; Zaid 2012, 2015; Sharma et al. 2013; Srivastava et al. 2013; Absar and Sreenivas 2015; Absar et al. 2016; Madhavaraju et al. 2016; Nagarajan et al. 2017; Pandey and Parcha 2017; Periasamy and Venkateshwarlu 2017; Zaid 2017).

The chemical composition of clastic sedimentary rocks is a function of a complex relationship of several variables, including the source rock composition, the extent of weathering, transportation and diagenesis (Taylor and McLennan 1985; Bhatia and Cook 1986; Roser and Korsch 1986; Cullers 1995; Sun et al. 2012; Zaid 2012). Besides, the tectonic setting of the sedimentary basin may play a predominant role over other factors, because different tectonic settings can provide different kinds of source materials with variable chemical signatures (e.g., Sun et al. 2012). Traditional petrographic analyses reveal the processes associated with provenance, environment of deposition and transportation of clastic materials (Dickinson and Suczek 1979; Ingersoll and Suczek 1979; Dickinson 1985). However, the framework of grains in sandstone is liable to be modified under burial and compaction, which can mislead the final inference. Whereas, the precision of geochemical data enable researchers to understand in detail the information contained in clastic sedimentary rocks (McLennan et al. 1993; Kroonenberg 1994; Armstrong-Altrin et al. 2004, 2012, 2015).

The distribution of major elements in sandstone provides more insight on tectonic setting in terms of discrimination diagrams when rocks are not altered (Bhatia 1983; Roser and Korsch 1986; McLennan 1989; Nesbitt and Young 1989; Sharma et al. 2013). Trace and rare earth elements (REE) composition of sandstone and some elemental ratio can also reflect the provenance and tectonic settings of sedimentary basin due to their immobility during weathering, transportation, sedimentary processes and metamorphism (Holland 1978; McLennan et al. 1983; Armstrong-Altrin and Verma 2005; Verma and Armstrong-Altrin 2013; Kassi et al. 2015; Zaid 2015; Periasamy and Venkateshwarlu 2017).

Significant contributions have been made in respect of the regional geology, stratigraphy, sedimentary facies analysis, tectonics, deformational structures and volcanism in the Pranhita-Godavari
Valley basin of Western Belt in Telangana as well as in Eastern Belt of Chhattisgarh-Maharashtra States (Chaudhuri 1985; Chaudhuri and Howard 1985; Sreenivasa Rao 1987; Chakraborty 1991; Chakraborty and Chaudhuri 1993; Saha and Chaudhuri 2003; Mukharjee et al. 2007; Saha and Deb 2014; Amarasinghe et al. 2015; Chaudhuri et al. 2015; Rao et al. 2017). But so far, the published literature of the aforementioned researchers, including that of Chaudhuri et al. (2015) and Amarasinghe et al. (2015), do not reflect the continuity of Proterozoic rocks between Dhaba and Pomburna in the Eastern Belt of the PG Valley in northern extension of Somanpalli Group in Chandrapur District of Maharashtra (figure 1A). The existence of Proterozoic sediments in this gap area on the eastern part of the PG Valley about $210 \mathrm{~km}$ from Nagpur city in Maharashtra were reported by a team of geologists from Geological Survey India, Nagpur (figure 1B). However, the stratigraphic succession, depositional environment, tectonic setting and geo-chemical signatures of the sediments is being studied for the first time by the present authors. The main objective of the study is to evaluate the major and trace element geochemistry and petro-fabric analysis of newly reported sandstones in order to decipher their provenance, tectonic setting and weathering conditions prevailing in the provenance.

\section{Geological outline of PG Valley}

The Pranhita-Godavari (PG) Valley of central India preserves records of repeated opening and closing of Proterozoic and Gondwana rifts along the zone of NW-SE trending Neo-Archaean suture between the Dharwar and Bastar cratonic nuclei (figure 1A) (Naqvi and Rogers 1987). The PG Valley, constituting an important part of Purana basin in the southern part of the Indian Peninsula, has received considerable attention in recent years. The PG Valley covers parts of erstwhile Andhra Pradesh, Maharashtra and Bastar region of Chhattisgarh, formed along a tectonic join between the Dharwar and Bastar cratons (Naqvi and Rogers 1987; Chaudhuri et al. 1989; Saha and Deb 2014), following the general orientation of the Godavari river valley and preserves a thick succession of Mesoproterozoic to Neoproterozoic sedimentary rocks unconformably overlying the Archaean-Palaeoproterozoic basement. The PG Valley is a $450 \mathrm{~km}$ NW-SE trending major lineament, comprising basin-filled sedimentary rocks 


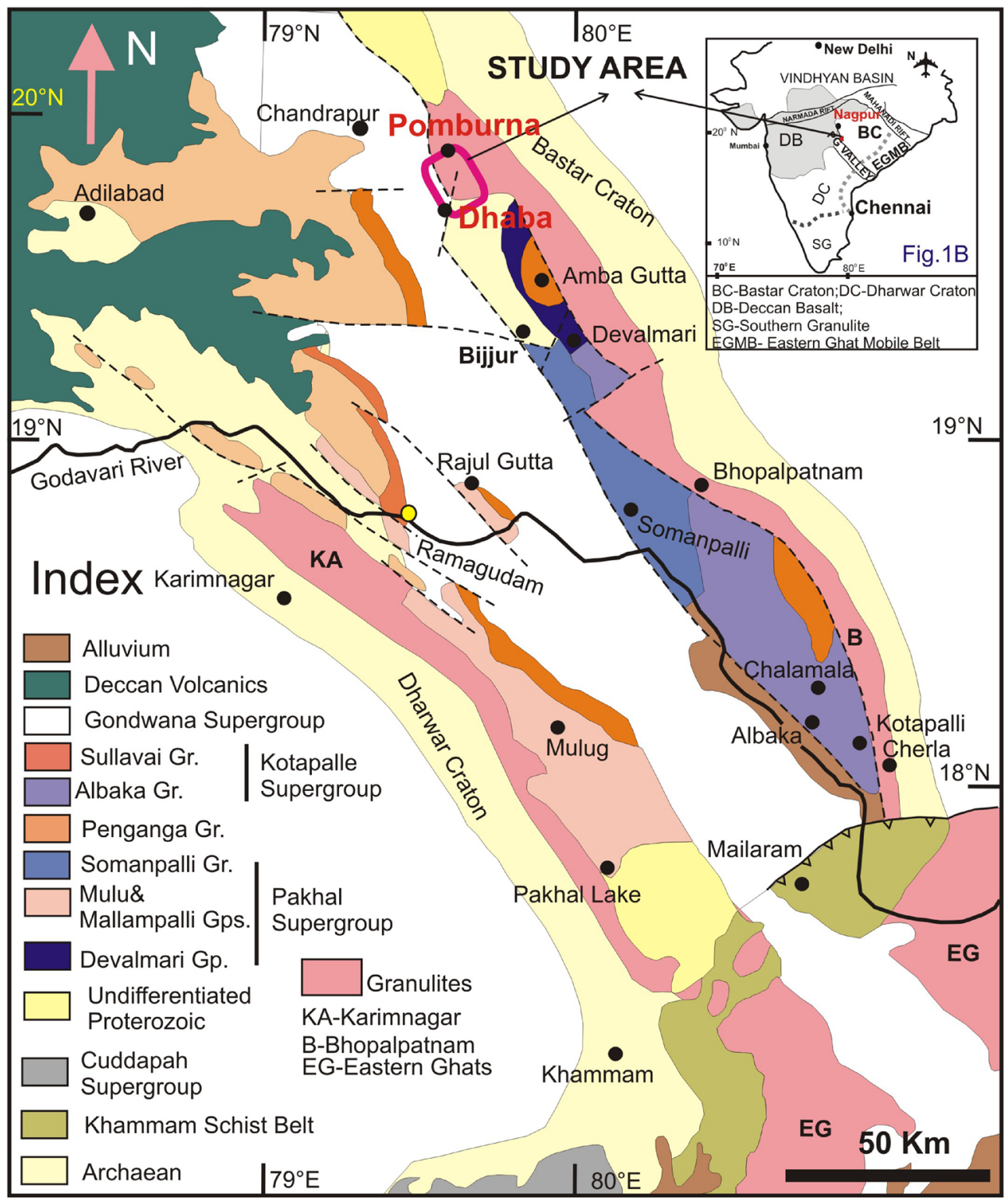

Figure 1. (A) Generalized regional geological map of the Pranhita-Godavari Valley modified after Chaudhuri et al. (2015) and Amarasinghe et al. (2015) showing distribution of the Purana sequences and Permian Mesozoic Gondwana Supergroup occurs along the join of the Bastar and Dharwar cratons. (B) Location map of Pomburna area in the Eastern Belt of PG Valley, central India, after Naqvi and Rogers (1987).

and extending from the Eastern Ghats Granulite Belt (EGGB) in the SE to the Central Indian Tectonic Zone (CITZ) in the NW. The average width of the exposed rock succession of the PG Valley is about $110 \mathrm{~km}$. The basin is generally referred to as the Godavari basin and constitutes the most important Proterozoic rift basin in the South Indian craton (Basumallick 1967), though there are dissenting views (Sreenivasa Rao 1987).

The Proterozoic rocks of the PG Valley represent almost a complete succession between the Archaean granitic basement and the Palaeozoic to Mesozoic Gondwana rocks (table 1). The depositional contacts between the basement and the Proterozoic succession, as well as the individual lithological units of Gondwana, are broadly linear and follow the NW-SE trend of the valley. The Purana rocks crop out in two NW-SE trending linear belts along the SW margin (Western Belt) and NE margin (Eastern Belt) of the valley. The SW margin of the Western Belt is bounded by granites and granulites of the Karimnagar Granulite Belt with a peak metamorphism age of ca. $2600 \mathrm{Ma}$, whereas the NE margin of the Eastern Belt is delineated by the Bhopalpatnam Granulite Belt with a peak metamorphism age of ca. $1600 \mathrm{Ma}$ 
Table 1. Stratigraphy of the PG Valley after Basumallick (1967), Srinivasa Rao et al. (1979), Saha and Ghosh (1998) and Chaudhuri et al. (2012).

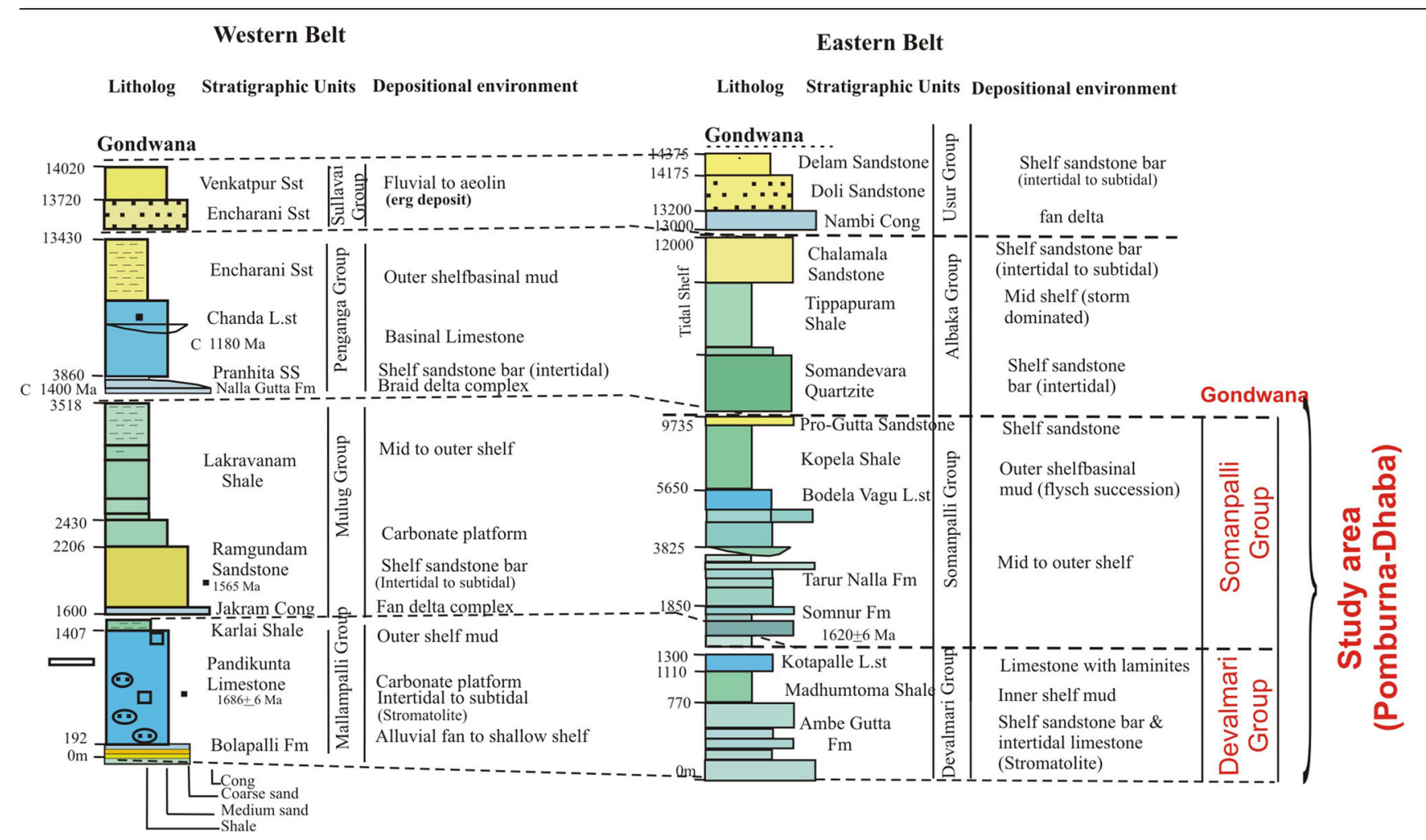

(Rajesham et al. 1993; Santosh et al. 2004) (figure 1A). The Eastern Belt occurs as a faultslice, bounded by two major NW-SE trending faults. The faults separate the Purana outcrops from the Gondwana succession in the west, and from the Bhopalpatnam Granulite Belt on the east and merge near Cherla in the SE and the BijjurDevalmari area in the NW (figure 1B) (Saha and Ghosh 1998; Chaudhuri et al. 2015), named as Somanpalli Group. Glauconite from the Somanpalli Group in the Eastern Belt of the PranhitaGodavari Valley gave an age of $1620 \pm 6 \mathrm{Ma}$ (Conrad et al. 2011). This belt is much less studied as compared to the Western Belt, and majority of the attempts were focused on the classification of the succession in the Albaka plateau in the southern part of the belt (Srinivasa Rao et al. 1979). The present study area is confined to central part of Eastern Belt in the northern extension of Somanpalli Group in Pomburna area of Chandrapur District of Maharashtra (figure 1A and table 1).

\subsection{Geology of the Dhaba-Pomburna area}

The study area comprises of 1000-1500 m thick deformed and undeformed Proterozoic sedimentary sequence, exposed over $20 \mathrm{~km}$ strike length, between Pomburna and Dhaba outlines bounded by Archaean basement rocks in the east and fault controlled linear Gondwana rocks in the west (figure 2A). The Archaean rocks exposed in the east include hornblendegneiss, quartzo-feldspathic gneiss, charnockite, meta-pyroxenite and gabbro intruded by undeformed Mesoproterzoic granite (Sashidharan and Ganvir 2004; Mukharjee et al. 2007; Sashidharan 2007; Dora 2012; Dora and Randive 2015; Rao et al. 2017). Sedimentary sequences are similar to Devalmari and Somanpalli Groups, and comprise a cyclic arenite-pelite-carbonate association, exposed near Dongargaon, Gondpipri, Gojoli, Dubarpet, Chintal Dhaba, Kimara, Dewada Khurd, Dongarhaldi and Jam Tukum (figure 2A).

A sequence of siliciclastic with preserved thickness of $300 \mathrm{~m}$ at the south-eastern extremity of the Eastern Belt with a basal phyllite and conglomerate grading up to quartz-arenite and subordinate dolomitic limestone, occurs in a fault bounded outcrops near Dongargaon (figures $2 \mathrm{~A}$ and $3 \mathrm{~A}-$ B). This lithological assemblage looks similar to that of the Cherla Formation (Srinivasa Rao et al. 1979) and Devalmari Group (Chaudhuri et al. 


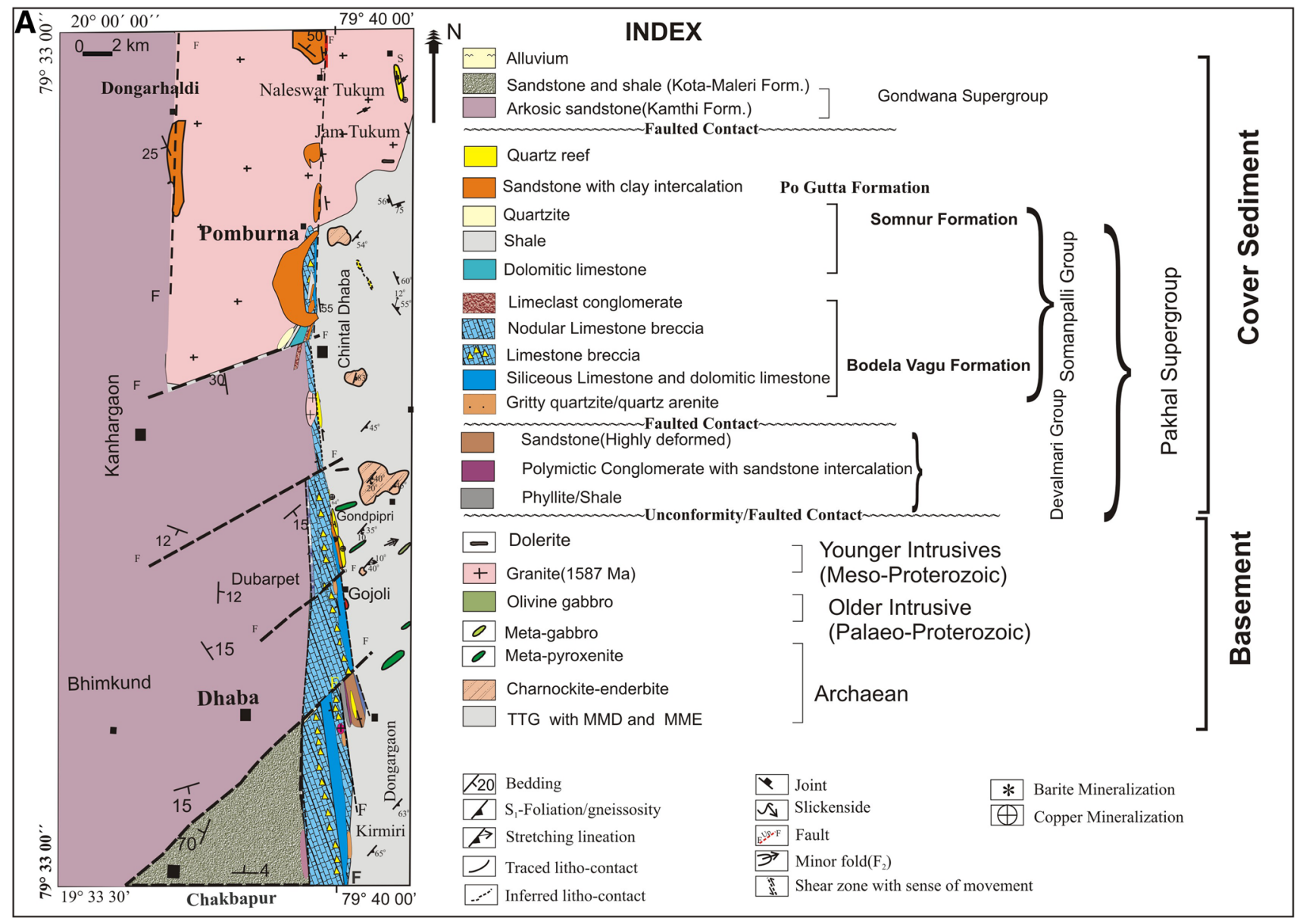

Figure 2. (A) Geological map of the Pomburna-Dhaba area of a portion of Eastern Belt of PG Valley, along the western margin of Bastar craton, central India (modified after Dora 2012). (B) Lithologic column of Bodela Vagu Formation of Somanpalli Group along borehole no. DPG 13 at Dubarpet $\mathrm{Cu}$ deposit.

2012) in eastern(?) and western(?) extension of type area of Somanpalli Group (Saha and Ghosh 1998), respectively. The sequence is overlain by rocks carbonates in lower horizon, arenaceousargillaceous in middle and arenaceous in the upper part (Saha and Ghosh 1998). The Carbonate sediments have strong similarities to the Bodela Vagu Formation of Somanapalli Group with lithological association of argillaceous limestone, dolomitic limestone and dolomite breccia exposed near Gojoli village south of Gondpipari (figures $2 \mathrm{~B}$ and $3 \mathrm{C}-$ $\mathrm{D})$. This sequence is overlain by limestone-shale near Kimara (figure 3E). However, the detailed stratigraphic description is beyond the scope of this paper.

The present study is confined to middle and upper sequence of the Somanpalli Group, comprising of sandstone, limestone and shale, exposed between Duberpeth in south and Naleswar Khurd in the north, occurring unconformably over Proterozoic granite (figure 3F), similar to Somnur and
Po Gutta Formation (table 1). Quartz rich, well sorted sandstones, cross-bedded and ferruginous at places is the dominant lithologies exposed in upper sequence near Jamtukum, Naleswar Tukum, which is considered as belong to Po Gutta Formation. Thickness of the sediments varies from 500 to $800 \mathrm{~m}$. At places, pebbly horizon in the massive sandstone indicate the deposition of sediments in a tectonically unstable environment. Various primary sedimentary structures like planar, trough and herringbone cross stratification and ripple marks (figure 3G and $\mathrm{H}$ ) are observed in the study area. Rip-up clasts are also present in purple sandstones, indicating interruptions in deposition with periods of erosion due to sea level fluctuations. Facies analysis in this area suggests that these deposits belong to a tidal flat depositional environment. The sandstone beds are intensely fractured and show evidences of malachite, bornite stains, and at places, filled by secondary calcite veins and barite veins. 


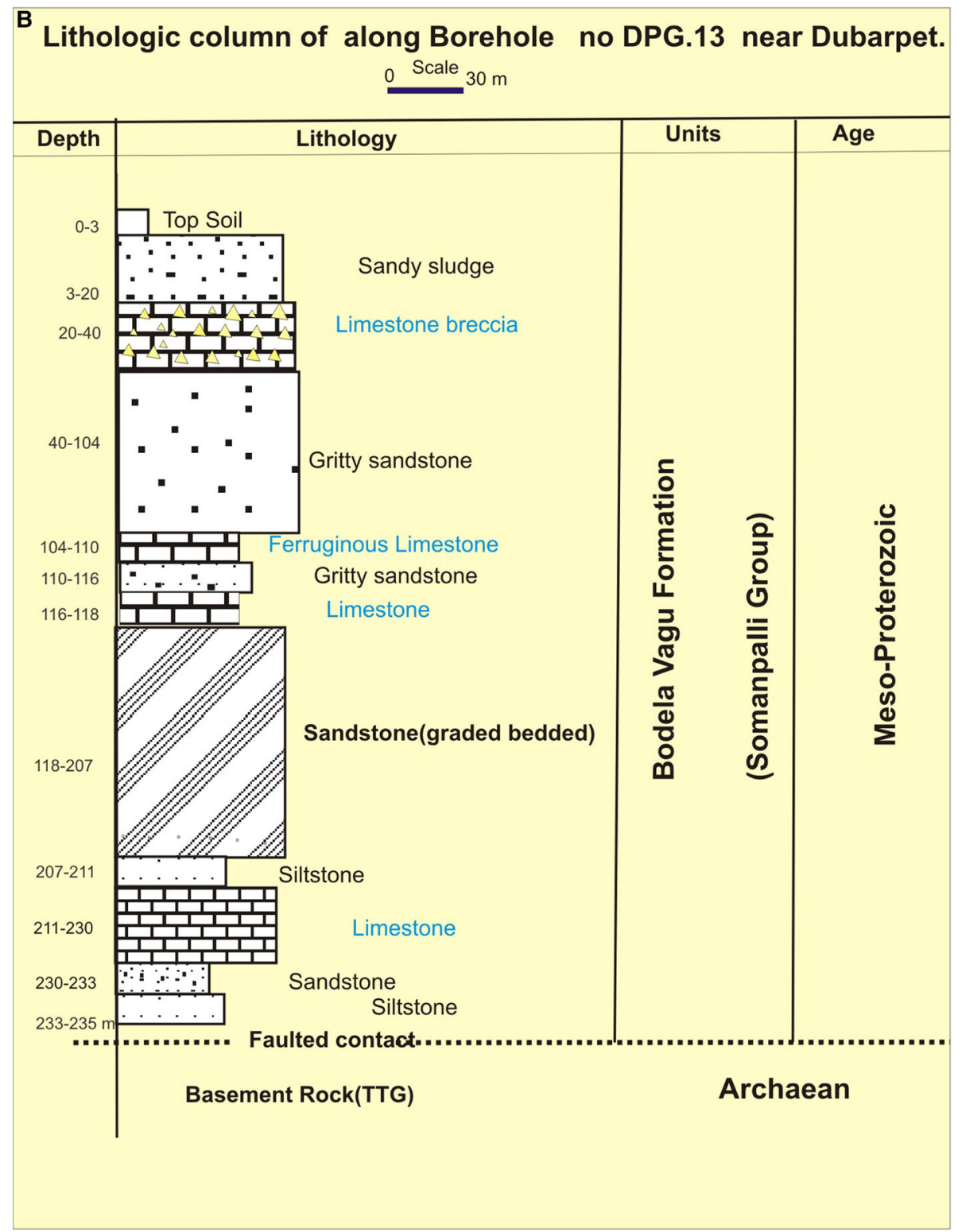

Figure 2. (Continued.)

\section{Material and analytical methods}

Field investigations were carried out on the sandstone members of Somanpalli Group in Pomburna area to examine their spatial distribution, variation in composition and nature of basement. A few key areas were also mapped in 1:5000; 12,500 and 25,000 scale (Mukharjee et al. 2007; Mahapatra et al. 2010; Dora 2012). Fresh representative sandstone samples $(4-5 \mathrm{~kg})$ were collected from the study area, i.e., Dongargaon, Chintaldhaba, Pomburna, DewadaKhurd, Jam Tukum and Dongarhaldi (figure 2) from outcrops, quarry sections and drill cores from Dubarpet. One part of each sample is used for preparation of thin section and the other part was powdered into - 120 mesh by using an agate mortar for chemical analysis. Modal analyses of the samples are carried out by conventional grain counting method. About 225-385 grains are counted for 12 numbers of thin sections. A total of 15 samples were considered for geochemical analysis. Thin sections of fresh, medium to coarse grained sandstone samples, collected from the fresh exposed sections. The chemical analyses were carried out for major, trace and REE at Chemical Division, Geological Survey of India, Nagpur. Major oxide and few trace elements data were analyzed using Wave Length Dispersive XRF system (XRF-2424, MAGIXS from M/S Pan Analytical, Netherlands). Major and 


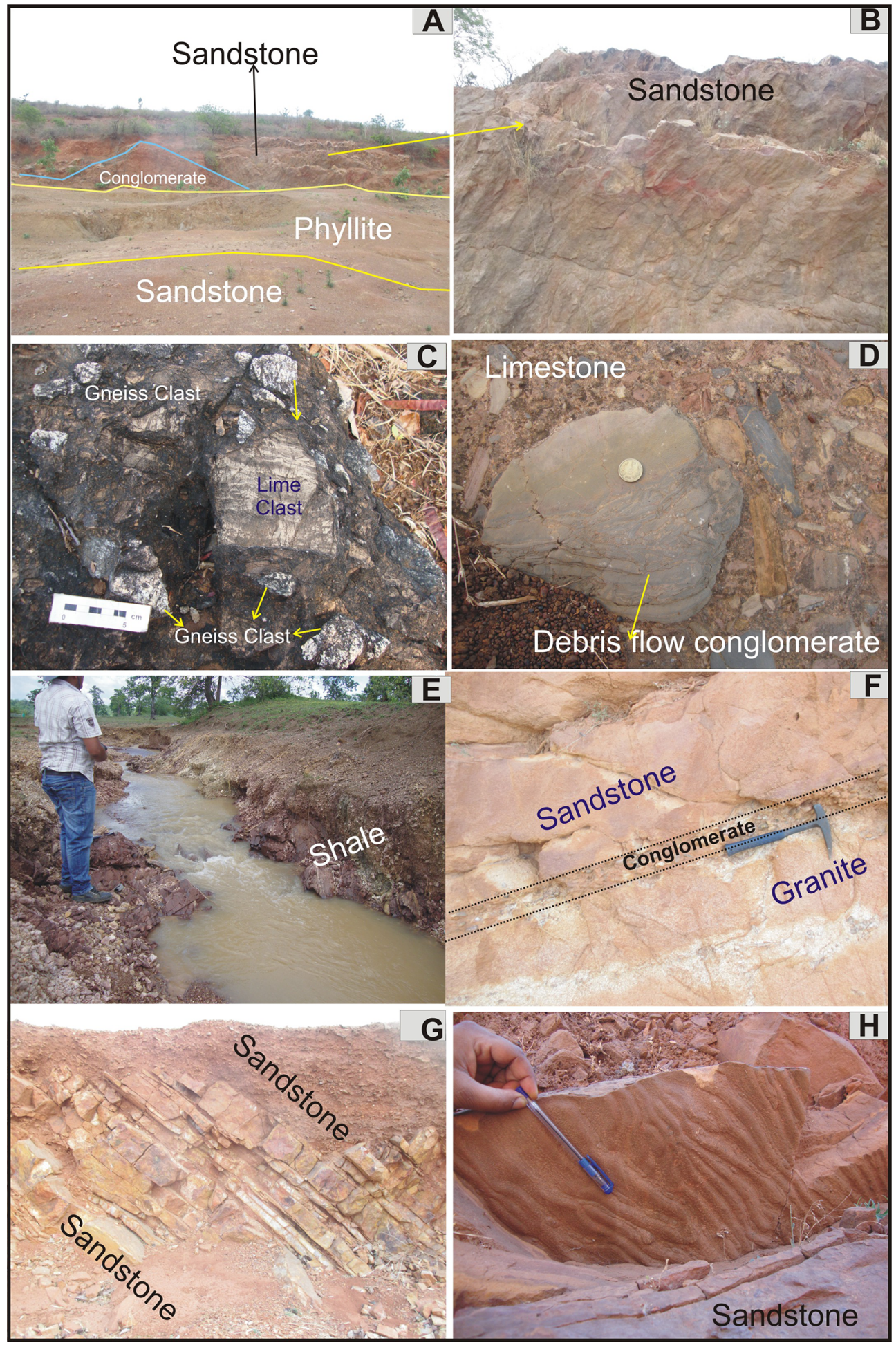

Figure 3. Outcrop features of the Devalamari and Somanpalli Group along Eastern Belt of PG Valley along western margin of Bastar craton, central India. (A-B) General view of the deformed sandstone along with folded intraformational conglomerate in the vicinity of near Dongargaon village and the locally faulted boundary with Bodela Vagu Formation of Somanpalli, (C-D) brecciated limestone of lower sequence of Bodela Vagu Formation west of Dongargaon hill, (E) highly jointed shale exposed near Chintaldhaba, (F) unconformable contact between purple sandstones of Proterozoic with Mesoproterozoic granite exposed NW of Naleswar Tukum, $(\mathbf{G}-\mathbf{H})$ purple sandstones with steep bed and symmetric as well as branching ripples near Naleswar Khurd. 
trace elements were analysed using pressed powder pellet mode of sample preparation and the analytical accuracy is better than $\pm 0.5 \%$. The total iron is expressed as $\mathrm{Fe}_{2} \mathrm{O}_{3}$. The major and trace element data were not recalculated to $100 \%$ because of loss of ignition is very less $<1.25 \%$. The concentrations of trace elements, such as $\mathrm{Cu}, \mathrm{Pb}, \mathrm{Zn}, \mathrm{Ag}$, $\mathrm{Cr}, \mathrm{Ni}$ and $\mathrm{Co}$, were determined by Atomic Absorption Spectrometry (AAS) (Spectra 220-FS) at Chemical Laboratory, GSI, Nagpur. Plasma Mass Spectrometry (ICP-MS; Elan DRC-e Perkin Elmer SCIEX, AH16901006) was used to acquire REE data. The details of techniques, procedure, precision and accuracy of these analyses are described in Standard Operating Procedure (SOP) (http:// www.portal.gsi.gov.in). Trace and REE data were normalized to chondrite values and Upper Continental Crust (UCC) of Taylor and McLennan (1985) and Sun and McDonough (1989).

\section{Results}

\subsection{Sandstone petrography}

The petrographic study revealed that the sandstones are characterized by fine to coarse grained detrital quartz, well sorted and sub-matured with fair amount of ferruginous and siliceous matrix. Occasional purple-red colouration is attributed to iron oxide pigmentation during diagenesis. Roundness of grains and maturity of sandstone increases towards upper horizons in the same section. The framework grains of sandstones are made of monocrystalline quartz $(\mathrm{Qm})$, polycrystalline quartz (Qp), undulatory monocrystalline quartz $(\mathrm{Qu}), \mathrm{K}$ feldspar, plagioclase and lithic fragments.

Quartz is predominant detrital grains and is of strained, unstrained and polycrystalline varieties with high Qm/Qp ratio. Quartz is sub-rounded to sub-angular with mechanical fractures (figure $4 \mathrm{~A}-\mathrm{D})$ and on an average monocrystalline quartz $(85-87 \%)$ dominates over polycrystalline quartz (5-10\%) (figure 4E-F). Sub-rounded to sub-angular feldspars (both plagioclase and Kfeldspar) are present in considerable amount. Kfeldspar is altered and show mainly cross-hatched twinning (microcline), at places with subordinate orthoclase and plagioclase (figure $4 \mathrm{E}$ and G). Plagioclase shows polysynthetic twinning at places, on an average lithic fragments in the samples comprise of $5-7 \%$ of the modal percentage. The sandstones are cemented with both siliceous and ferruginous cement (figure 4F). Overall fining in grain size and increase in textural maturity is observed in up-section direction. For instance, the basal portion of sandstone is gritty and poorly sorted, showing large range in size of framework grains $(0.08-0.6 \mathrm{~mm}$, sometimes reaching up to $8 \mathrm{~mm}$ ) of sub-angular to angular quartz passing upward to medium- to coarse-grained at places. Roundness and sorting increase upwards, with concomitant reduction in size of feldspars compared to quartz. The member successively becomes a well sorted medium to coarse-grained sub-arkose and quartz arenite consisting of rounded to sub-rounded grains of quartz with little feldspar (table 2). Quartzite at Dongargaon and Jam Tukumis often deformed with the development of sutured contacts and at places, parallel alignment of elongated quartz grains.

The dominant accessory heavy minerals are mainly opaque minerals (ilmenite, magnetite and hematite). The non-opaque minerals include zircon and tourmaline (figure $4 \mathrm{G}$ and $\mathrm{H}$ ). The modal percentage of quartz, feldspar and lithic fragments from the studied samples are mono- and polycrystalline quartz (85-87\%), alkali feldspar (5$10 \%$, mostly K-feldspar and microcline), and lithic fragments (5-7\%). According to their mineral compositions, these sandstones can be classified as quartz arenite and sub-arkose in QFL diagram (figure $5 \mathrm{~A}$ ), and also plotted in continental-recycled orogen provenance (figure 5B) of Dickinson (1985).

\subsection{Geochemistry}

The major and trace element concentrations of sandstones of the Somanpalli Group from six locations are presented in tables 2-4, respectively and sample locations are given in figure 2. For comparison in elemental abundances, average values of Upper Continental Crust (UCC) after McLennan (2001) and Taylor and McLennan (1985) are included as a reference. Using the geochemical classification scheme of Blatt et al. (1972), the sandstones of Pomburna area are classified as albitized sandstones (figure 5C).

\subsubsection{Major oxides}

The sandstone contains high concentration of $\mathrm{SiO}_{2}$ ( 83.58 to $90.75 \%$; average $88 \%$ ) and $\mathrm{Al}_{2} \mathrm{O}_{3}$ content (ranging from 3.29 to $7.96 \%$ and averaging $5.6 \%$, table 3). The $\mathrm{Al}_{2} \mathrm{O}_{3} / \mathrm{SiO}_{2}$ ratio ranges from 0.03 to 0.08 with an average of 0.06 , which is lower 


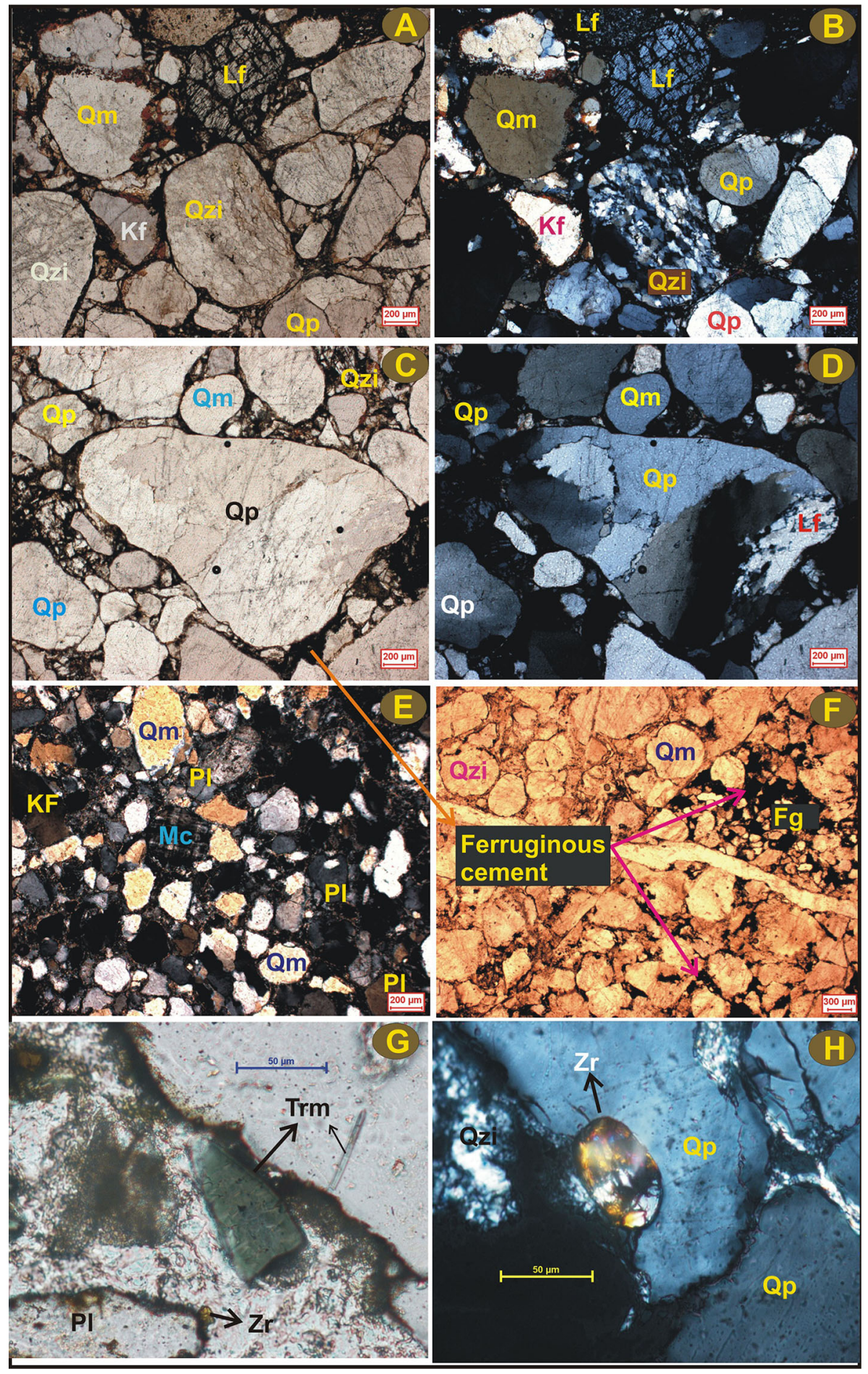

Figure 4. Photomicrographs of sandstones from Pomburna area, Somanpalli Group showing (A-H) Quartz arenite with monocrystalline quartz $(\mathrm{Qm})$, polycrystalline quartz $(\mathrm{Qp})$, undulose quartz $(\mathrm{Qu})$, K-feldspar (Kf), and iron cement under PPL; Quartz arenite show subrounded mono-crystalline quartz (Qm), and fresh K-feldspar (Kf), Quartz arenite with large size grains of monocrystalline quartz (Qm) showing mechanical fracture, Sandstone showing at places zircon and tourmaline heavies.

as compared to the UCC average (0.23) (table 3). This reflects the quartz enrichment and moderately mature nature of these sandstones, as was seen in the petrographic analysis. Plot of major elements vs. $\mathrm{SiO}_{2}$ content on a Harker Diagram (figure $6 \mathrm{~A}-\mathrm{F}$ ) illustrates the overall limited variation in major element geochemistry within the sandstones. Very strong to strong negative linear 
Table 2. Detrital modes of 11 selected samples from Pomburna sandstones, Eastern Belt, PG Valley.

\begin{tabular}{lccccc}
\hline \multirow{2}{*}{$\begin{array}{c}\text { Sl. } \\
\text { no. }\end{array}$} & \multirow{2}{*}{$\begin{array}{c}\text { nample } \\
\text { no. }\end{array}$} & \multicolumn{4}{c}{ Framework grains } \\
\cline { 3 - 6 } 1 & Qp and Qm & F & L & Sum \\
\hline 2 & GP4JU-2 & 330 & 45 & 9 & 384 \\
3 & GP4JU-3 & 236 & 30 & 12 & 278 \\
4 & GP4JU-4 & 240 & 15 & 9 & 286 \\
5 & GP4JU-5 & 335 & 48 & 4 & 263 \\
6 & GP4JU-7 & 268 & 19 & 11 & 395 \\
7 & GP4JU-10 & 196 & 16 & 13 & 225 \\
8 & GP4JU-14 & 260 & 30 & 20 & 310 \\
9 & GP4JU-12 & 220 & 20 & 10 & 250 \\
10 & GP4JU-15 & 300 & 33 & 10 & 343 \\
11 & GP4JU-17 & 200 & 20 & 10 & 230 \\
& Average, $n=11$ & 258.8 & 26.8 & 10.9 & 296.54 \\
\hline
\end{tabular}

correlation of $\mathrm{SiO}_{2}$ with the main major $\left(\mathrm{Al}_{2} \mathrm{O}_{3}\right.$, $\mathrm{Fe}_{2} \mathrm{O}_{3}, \mathrm{~K}_{2} \mathrm{O}, \mathrm{TiO}_{2}$ ) and trace elements ( $\mathrm{Cr}, \mathrm{Rb}$, $\mathrm{Ba}, \mathrm{V}, \mathrm{Ga})$ is attributed to sedimentary sorting and concentration of these elements in the clay fraction in Al-rich sediments, i.e., illite, which are depleted in quartz. The $\mathrm{K}_{2} \mathrm{O}$ and $\mathrm{Rb}$ contents in terrigenous sediments are sensitive to sedimentary recycling processes and have been widely used as indicators for source composition (ArmstrongAltrin et al. 2012; Tao et al. 2013). This K/Rb ratio is higher showing positive correlation along with $\mathrm{Rb} / \mathrm{Al}_{2} \mathrm{O}_{3}$.

The $\mathrm{K}_{2} \mathrm{O} / \mathrm{Al}_{2} \mathrm{O}_{3}$ ratios can be used to define the original composition of ancient sediments (Ramachandran et al. 2016). According to earlier researchers, the $\mathrm{K}_{2} \mathrm{O} / \mathrm{Al}_{2} \mathrm{O}_{3}$ ratio for clay minerals ranges from 0.1 to 0.3 and for feldspars range between 0.3 and 0.9 . In the present study, the $\mathrm{K}_{2} \mathrm{O} / \mathrm{Al}_{2} \mathrm{O}_{3}$ ratio ranges between 0.01 and 0.30 , suggests that the rocks contain presence of minor clay minerals like illite. Sandstone samples reflect highest $\mathrm{SiO}_{2}$ and low $\mathrm{Al}_{2} \mathrm{O}_{3}$, which further suggests presence of quartz and absence of Al-bearing mineral (Nagarajan et al. 2007). Sandstones, on an average, are slightly enriched in $\mathrm{SiO}_{2}$ (tables 1 and 2) in comparison with UCC data (McLennan 2001; Taylor and McLennan 1985), whereas average $\mathrm{Fe}_{2} \mathrm{O}_{3}(2.6 \%)$ and $\mathrm{MgO}(0.23 \%)$ are very less compared to UCC (5.03 and $2.20 \%$, respectively) (tables 3 and 4).

The sandstones are greatly depleted in $\mathrm{Al}_{2} \mathrm{O}_{3}$ and $\mathrm{TiO}_{2}$, and slightly depleted in $\mathrm{Na}_{2} \mathrm{O}$ and $\mathrm{K}_{2} \mathrm{O}$ relative to UCC. These differences might be due to quartz dilution related abundance of monoand poly-crystalline detrital quartz grains. On the
$\mathrm{Al}_{2} \mathrm{O}_{3} / \mathrm{TiO}_{2}$ vs. $\mathrm{SiO}_{2}$ adjacent plot of Le Bas et al. (1986) show that samples of Pomburna sandstone are felsic in composition (figure 7A).

\subsubsection{Trace elements}

Trace element concentrations of sandstone samples from Pomburna area are analysed and presented
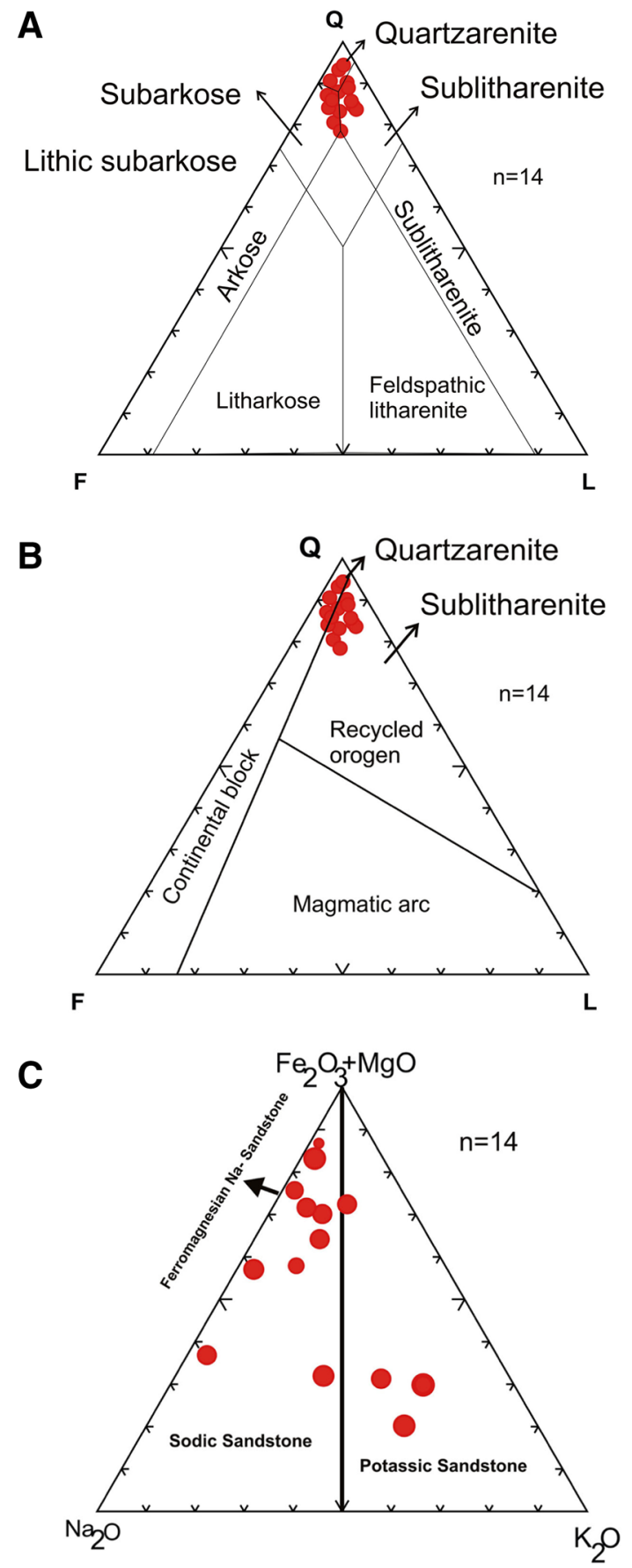

Figure 5. (A-B) QFL diagrams showing the mineralogical classification of the Pomburna sandstones (provenance fields after Dickinson 1985). (C) Chemical classification of triangular plot showing ferromagnesian Na-sandstone field after Blatt et al. (1972). 


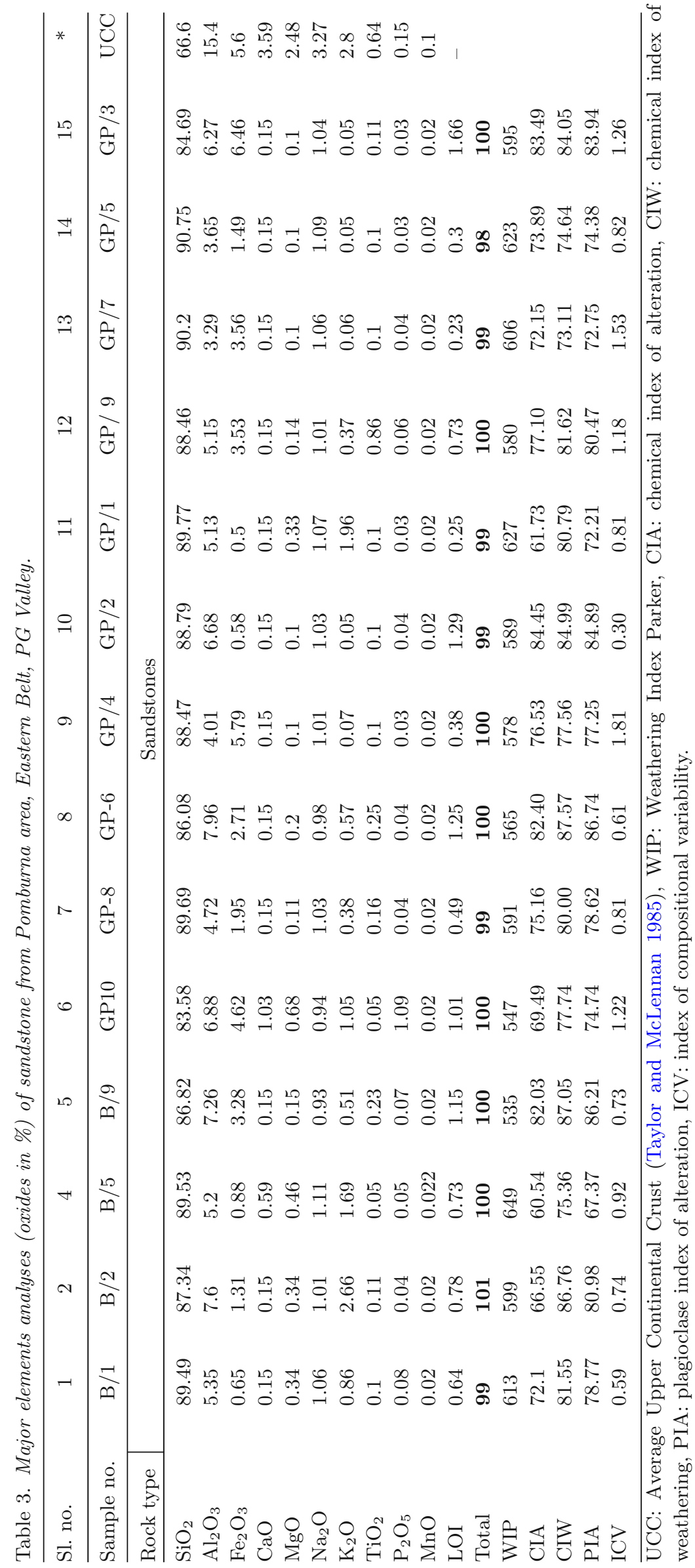




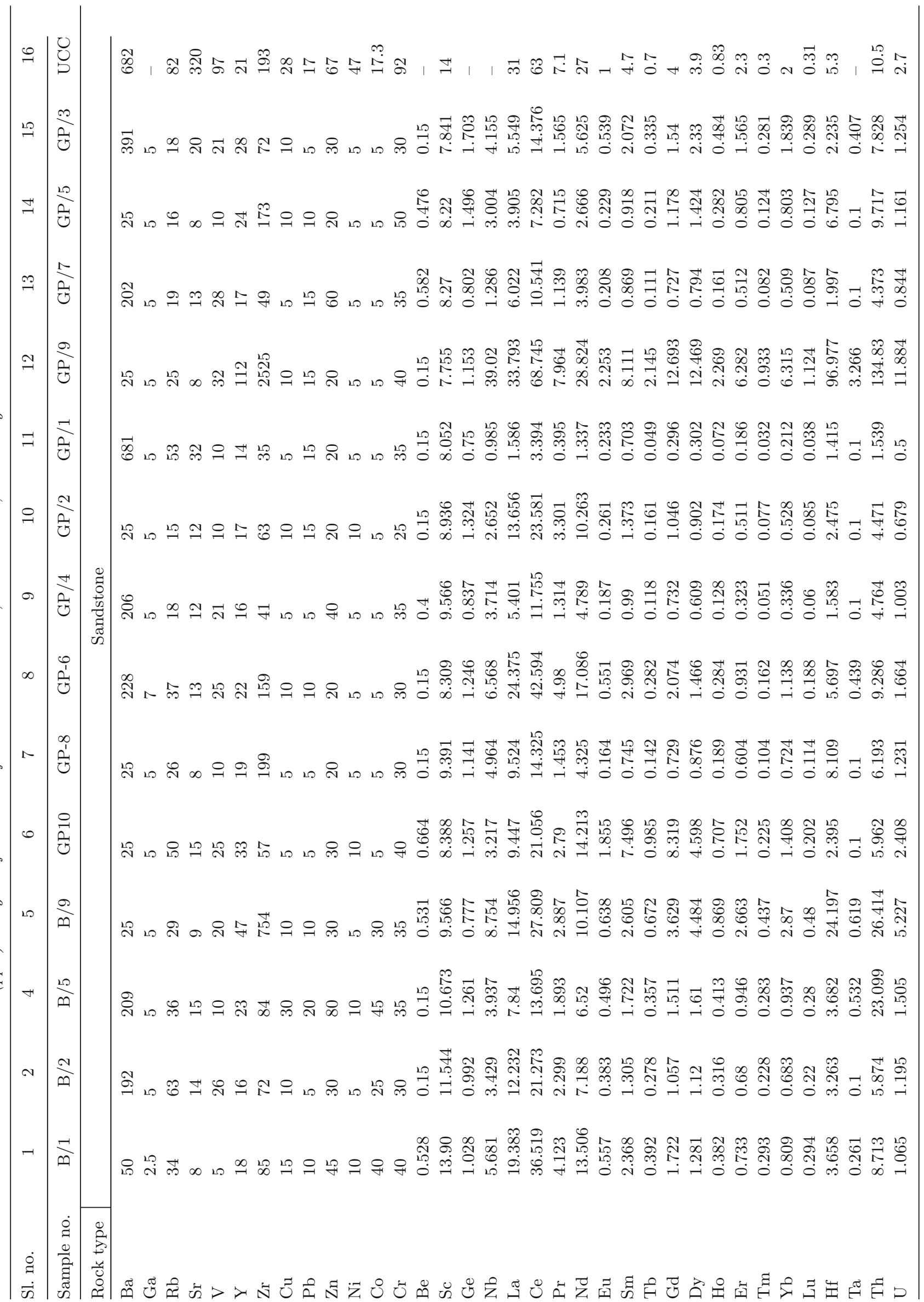



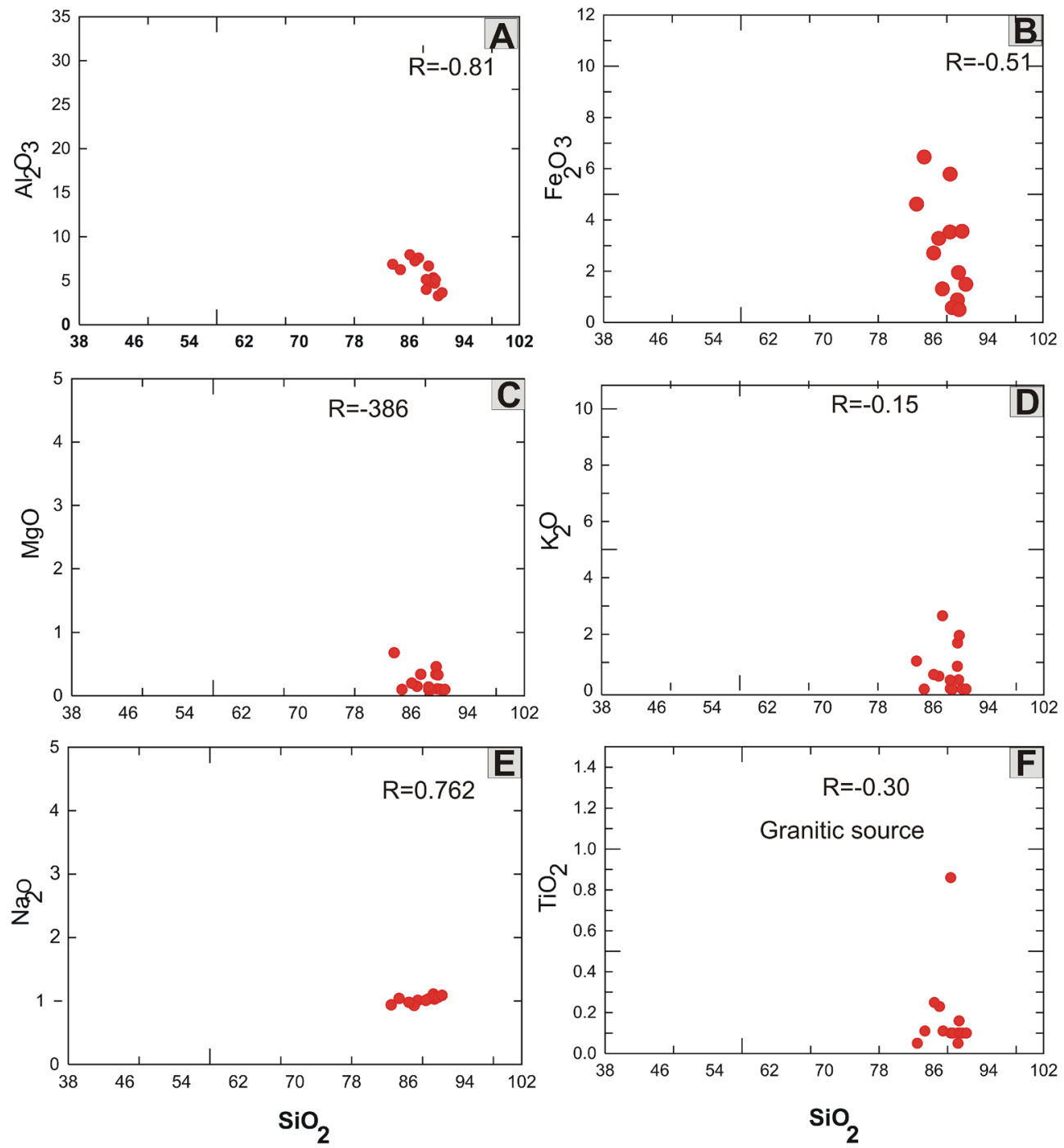

Figure 6. Harker variations diagram for Pomburna sandstone $(\mathbf{A}-\mathbf{F})$ variation of $\mathrm{SiO}_{2}$ vs. all major oxides showing positive and negative correlations.

in tables 4 and 5 . The distribution of trace elements in all the analyzed sandstone samples display relatively similar pattern normalized to UCC with depletion and enrichment of certain elements. The large-ion lithophile elements (LILE), such as $\mathrm{Rb}, \mathrm{Sr}, \mathrm{Cs}, \mathrm{Ba}, \mathrm{Th}$, and $\mathrm{U}$, are compared with UCC in which the Rb (15-63 ppm, $n=14)$, Sr (8-32 ppm, $n=14$ ) are slightly depleted in all sandstone types with minor enrichment of Th (4.37-134.83 ppm, $n=14)$ and $\mathrm{U}(0.67-11.88$ ppm, $n=14)$ in sandstone. The Ba $(25-681 \mathrm{ppm}$, $n=14$ ) concentrations in the sandstones are lower than in UCC, except one value. The LILE, i.e., $\mathrm{Rb}, \mathrm{Sr}$, and $\mathrm{U}$ are showing low positive correlation coefficient $(r=0.49,0.087$, and 0.079, respectively), $\mathrm{Ba}$ and $\mathrm{Th}$ are showing low negative correlation coefficient $(r=-0.036$ and -0.050 , respectively) with $\mathrm{Al}_{2} \mathrm{O}_{3}$. The $\mathrm{Rb} / \mathrm{Sr}$ ratios of the
Pomburna sandstones (2.34) are higher than the average post-Archaean Australian shale (0.80; Taylor and McLennan 1985). On the La/Sc vs. Th/Co and $\mathrm{La} / \mathrm{Th}$ vs. Hf bivarite diagram, sandstone of area plot near to silicic rock provenance composition (figure 7B and C; Floyd and Leveridge 1987). The distributions of trace elements $\mathrm{Th}$ and $\mathrm{U}$ in sandstones show slight enrichment and Sr, Ba show depletion as compared to UCC (figure 9A).

The concentrations of $\mathrm{Zr}$, and $\mathrm{Nb}$ (high-field strength elements, HFSE) are relatively lower compared to UCC, whereas Hf and Y are higher than UCC (table 4). Among HFSE, Zr (avg. = 312 ppm) and Hf (avg. = $29 \mathrm{ppm}$ ) are enriched in sandstones. Overall ratio of $\mathrm{Zr} / \mathrm{Hf}$ (22.0-32.2) (table 3) suggests presence of heavy minerals in the studied samples, confirmed by petrography study. The correlation of $\mathrm{Zr}$ with Hf (0.99) suggests that these 

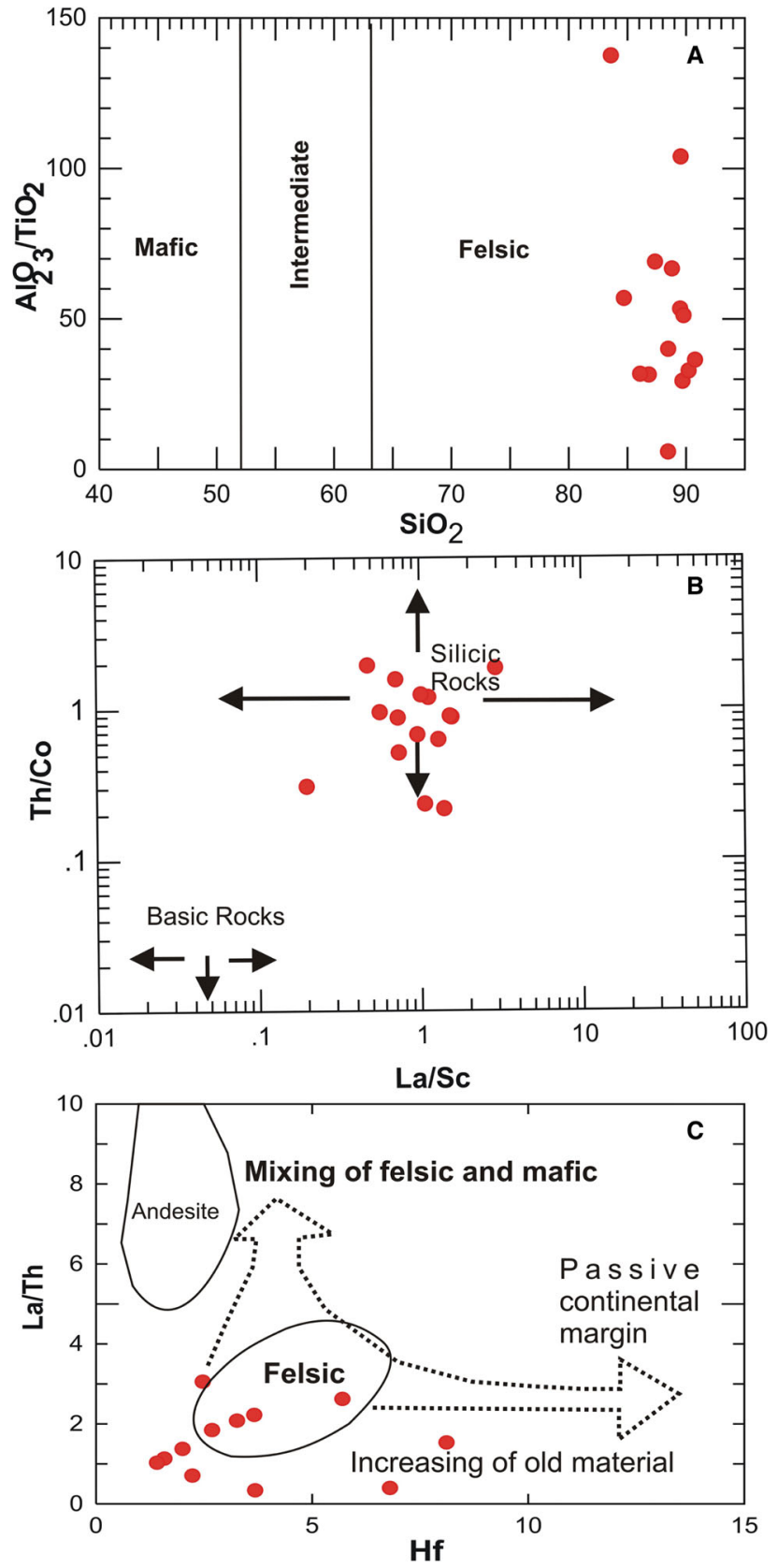

Figure 7. Bivariate plot of major and trace elements of Pomburna sandstones showing nature of felsic source and provenance: (A) $\mathrm{Al}_{2} \mathrm{O}_{3} / \mathrm{TiO}_{2}$ vs. $\mathrm{SiO}_{2}$ adj after Le Bas et al. (1986). (B) La/Sc vs. Th/Co after Cullers (2002). (C) La/Th vs. Hf diagrams after Floyd and Leveridge (1987).

elements are primarily controlled by zircon showing trend 2 in figure $8(\mathrm{~B})$.

The distribution of transition trace elements (TTE) Cr, Ni, Sc, Cu, and V in sandstones show slight depletion as compared to UCC, which can be attributed to absence of basic rocks in the source area. The $\mathrm{Cr}$ concentration in the samples varies from 25 to $40 \mathrm{ppm}$ and show strong

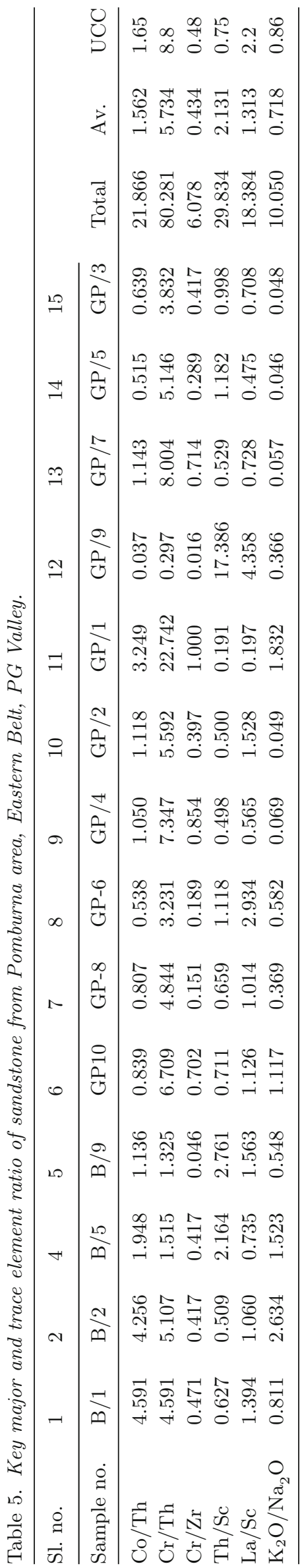



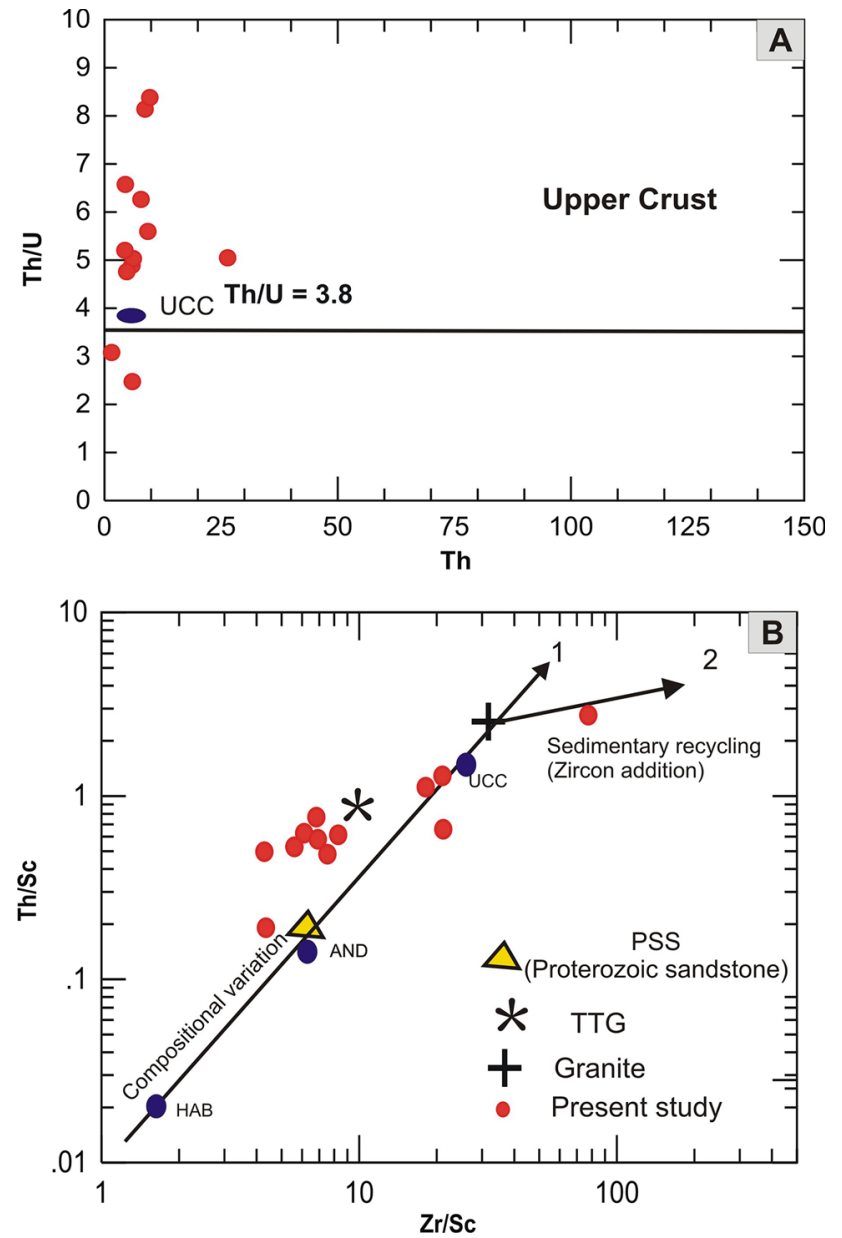

Figure 8. Trace element bivariate plot of Th/U vs. Th plot for the Pomburna sandstones showing above UCC (3.8). (B) Th/Sc vs. Zr/Sc diagram (after McLennan et al. 1993); Trend 1 represents sediments derived from igneous rocks and are less affected by sedimentary sorting and recycling. Trend 2 represents heavy mineral accumulation by sedimentary sorting and recycling. Average source rock compositions are of Proterozoic age (after Condie 1993). GRA, granite; TTG, tonalite-trondhjemite-granodiorite; PSS, Proterozoic sandstones. Baslat-HAB, Andesite-And and UCC values.

negative correlation with $\mathrm{Al}_{2} \mathrm{O}_{3}(r=-0.48, n=$ 14) implies to be incorporated into a clay minerals. In addition, $\mathrm{Ni}(r=0.16), \mathrm{Sc}(r=0.10), \mathrm{Cu}(r=$ $0.08)$ and $\mathrm{V}(r=0.22)$ also show low positive correlation with $\mathrm{Al}_{2} \mathrm{O}_{3}$ due to their association with non-phyllosilicates. The depletion of $\mathrm{Ni}$ in the studied samples indicates absence of mafic.

\subsubsection{Rare earth elements}

The chondrite-normalized values display pattern similar to UCC (figure 9A) with slight enrichment and depletion. Chondrite-normalized REE plot of siliciclastic rocks reflect enrichment of LREE and slight flat HREE pattern (figure 9B).
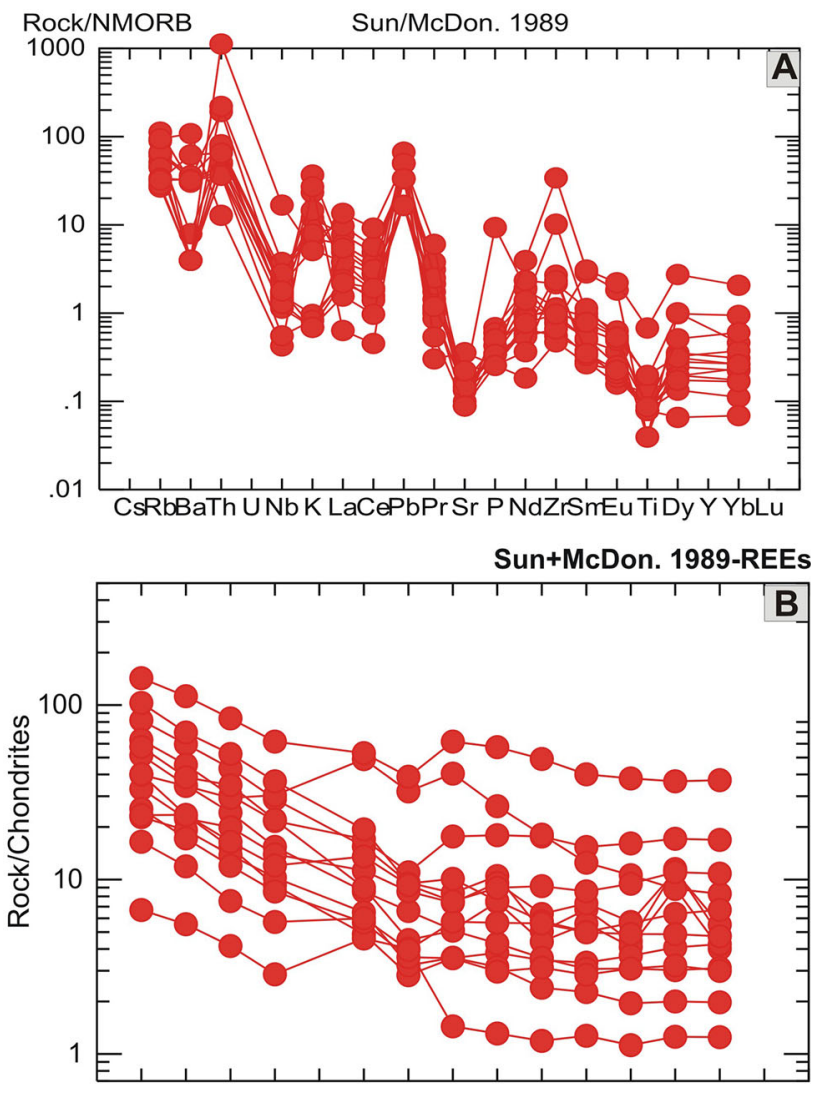

La Ce Pr NdPmSm Eu Gd Tb Dy Ho Er Tm Yb Lu

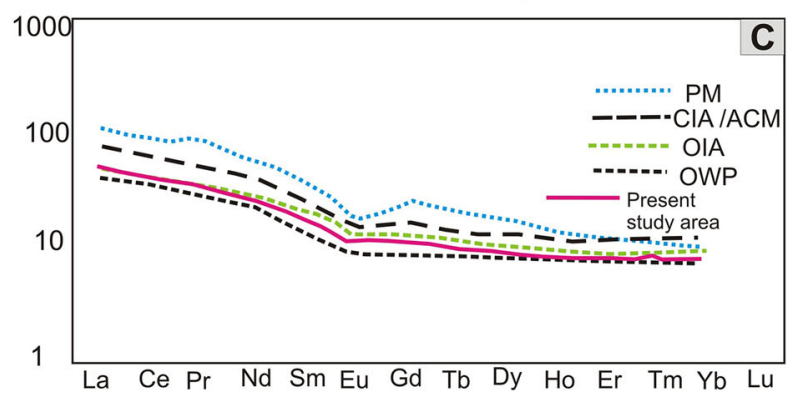

Figure 9. Multi-element normalized diagram of trace elements: (A) N-MORB normalized and (B) Chondrite normalized average REE after Sun and McDonough (1989). (C) Chondrite normalized average REE patterns for the Somanpalli Group chondrite normalized values are from Taylor and McLennan (1985). For comparison the REE patterns of sandstones from various tectonic settings are also included (Bhatia 1985; Bhatia and Cook 1986; Kutterolf et al. 2008). PM, passive margin; ACM, active continental margin; CIA, continental island arc; OIA, ocean island arc; OWP, oceanic within-plate.

The average chondrite normalized REE pattern of the Pomburna sandstone is shown in figure $9(\mathrm{C})$.

A positive correlation is observed between La and $\mathrm{Al}_{2} \mathrm{O}_{3}$ suggesting that in the study area the REE fractionation in the sediment is low and are derived mainly from the source/detrital 
components (Nath et al. 2000). The determined REE contents in the sandstones are given in table 4 . The average $\Sigma$ REE 58.83 concentrations of all sandstones from the Somanpalli Group are slightly higher than UCC values. The values of $\Sigma$ REE, HREE and LREE when correlated with $\mathrm{Al}_{2} \mathrm{O}_{3}$ show weak positive correlation $(n=$ 14) suggesting that non-phyllosilicates are hosting REE.

\section{Discussion}

Sandstones from Pomburna area are classified as quartz arenite and sub-litharenite based on quantitative petrographic studies. The dominance of different quartz grains (monocrystalline \{undulatory and non-undulatory $\}$ and polycrystalline) in these sandstones show granitic and/or gneissic source. Moreover, the greater abundance of alkali feldspar further supports granitic and/or gneissic source. The dominance of well sorted sediments either reflects change in water turbulence during deposition or pulses of sediment supply during episodes of rifting and uplift in PG Valley, in central India.

\subsection{Nature of source rocks and weathering conditions}

Major element geochemistry and mineralogy of siliciclastic sedimentary rocks is greatly influenced by the intensity of chemical weathering at the source region, physical sorting and diagenesis (Nesbitt and Young 1982; McLennan 1993). Generally feldspar is the more reactive mineral during chemical weathering and diagenesis which results in the formation of clay minerals (Nesbitt and Young 1982; Taylor and McLennan 1985).

The intensity and duration of weathering in clastic sediments can be evaluated by examining the relationships among alkali and alkaline earth elements (Nesbitt and Young 1996; Nesbitt et al. 1997). Alteration of rocks during weathering results in depletion of alkali and alkaline earth elements $\left(\mathrm{Ca}^{2+}, \mathrm{K}^{+}\right.$and $\left.\mathrm{Na}^{+}\right)$and preferential enrichment of $\mathrm{Al}^{3+}$ (figure 10A). The amount of these elements surviving in soil profile and associated sediments is a quantitative index of the intensity of weathering (Nesbitt et al. 1997). In weathering profile larger cations, e.g., $\mathrm{K}$ and $\mathrm{Rb}$, remain fixed in comparison to lower cations, e.g., Ca, Na, Sr. These chemical

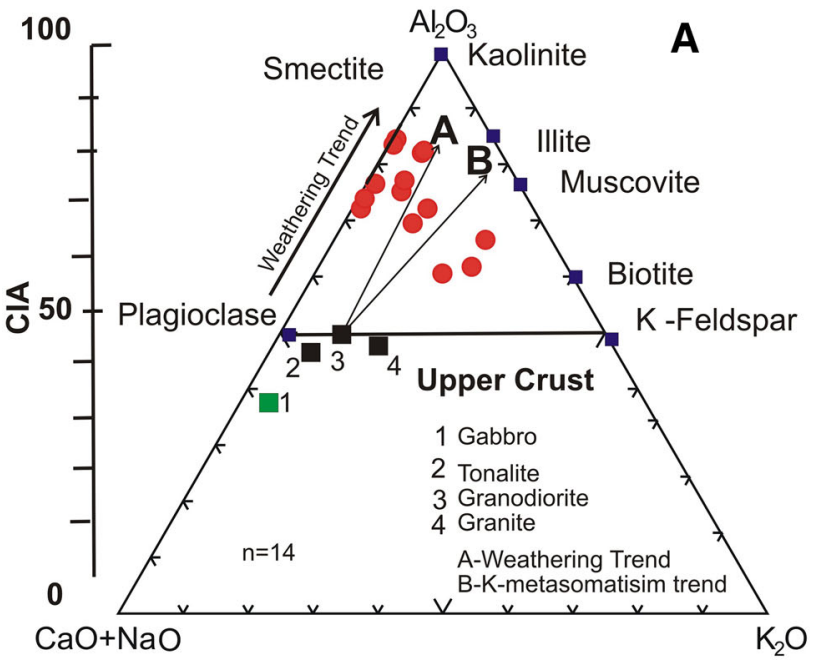

B

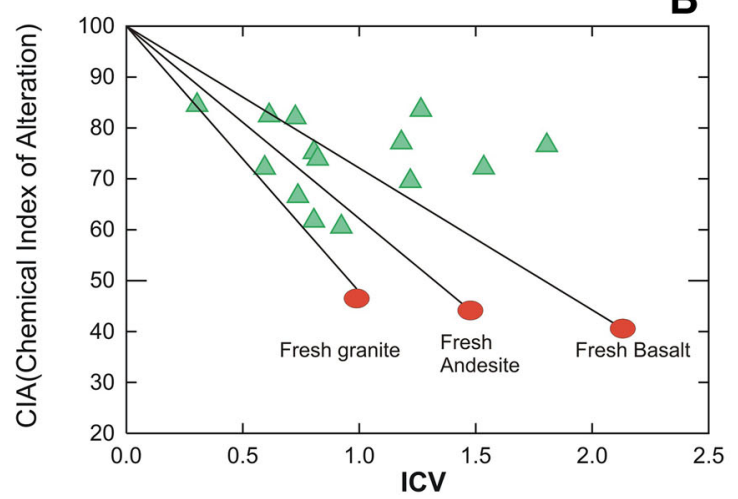

Figure 10. (A) A-CN-K ternary diagram of molecular proportions of $\mathrm{Al}_{2} \mathrm{O}_{3}-\left(\mathrm{CaO}+\mathrm{Na}_{2} \mathrm{O}\right)-\mathrm{K}_{2} \mathrm{O}$ for the Pomburna sandstones (after Nesbitt and Young 1984). Also plotted is the average upper continental crust, granite, tonalite, basalt and granodiorite (Taylor and McLennan 1985), as well as some rock forming minerals important in silicate rock weathering; shown at the side is the CIA scale. Arrows A-B represent the weathering trends of granodiorite, adamellite and granite, respectively and K-metasomatism trend (Nesbitt and Young 1984). (B) The ICV-CIA diagram (after Potter et al. 2005; Lamaskin et al. 2008) suggests mixed granite-andesite-basalt composition of source rocks.

signatures are transferred into the sedimentary record and is useful to define the source area weathering condition (Nesbitt and Young 1982, 1984; McLennan et al. 1993; Fedo et al. 1995).

Chemical Index of Alteration (CIA) proposed by Nesbitt and Young (1982), index of compositional variability (ICV) by Cox et al. (1995) and the chemical index of weathering (CIW) (Harnois 1988) were used to interpret the degree of chemical weathering in source area and compositional maturity of Pomburna sandstone (figure 10A). This can be calculated using formula (molecular proportion) 


$$
\begin{aligned}
\mathrm{CIA}= & \left\{\mathrm{Al}_{2} \mathrm{O}_{3} /\left(\mathrm{Al}_{2} \mathrm{O}_{3}+\mathrm{CaO}^{*}+\mathrm{Na}_{2} \mathrm{O}+\mathrm{K}_{2} \mathrm{O}\right)\right\} \\
& \times 100 \\
\mathrm{CIW}= & 100 \times \mathrm{Al}_{2} \mathrm{O}_{3} /\left(\mathrm{Al}_{2} \mathrm{O}_{3}+\mathrm{CaO}^{*}+\mathrm{Na}_{2} \mathrm{O}\right) \\
\mathrm{ICV}= & \left\{\mathrm{Fe}_{2} \mathrm{O}_{3}+\mathrm{K}_{2} \mathrm{O}+\mathrm{Na}_{2} \mathrm{O}+\mathrm{CaO}+\mathrm{MgO}\right. \\
& \left.+\mathrm{MnO}+\mathrm{TiO}_{2}\right\} / \mathrm{Al}_{2} \mathrm{O}_{3}
\end{aligned}
$$

${ }^{*} \mathrm{CaO}$ is the $\mathrm{CaO}$ in silicate fraction.

The higher CIA values ranging between 70 and 100 indicate the intensive chemical weathering and reflect warm and/or humid condition in source areas (Nesbitt and Young 1982; Fedo et al. 1995), whereas, values $<50$ indicate near absence of chemical alteration and reflect cool and/or arid conditions or unweathered source areas (McLennan et al. 1983; Fedo et al. 1995).

In the present study, the analyzed CIA values range from 60 to 84 with an average of $\sim 74$ (tables 3 and 4) (figure 10A and B), while basal gritty feldspar rich unit show lower CIA values. The CIA values of samples indicate moderate to intensive chemical weathering (Armstrong-Altrin et al. 2015). The calculated CIW values of the sandstones range from 73 to 87 (mean $=80$, Mongelli et al. 2006) indicates moderate to intensive weathering under warm and/or humid condition in source areas resulting alteration and destruction of feldspar and other labile minerals. Paleo-weathering condition can also be detected by $\mathrm{A}-\mathrm{CN}-\mathrm{K}$ ternary diagram, which is also used to evaluate the mobility of elements during the progress of chemical weathering (Nesbitt and Young 1984). The CIA values of Pomburna sandstone are plotted on $\mathrm{A}-\mathrm{CN}-\mathrm{K}$ ternary diagram (figure 10A). In the $\mathrm{A}-\mathrm{CN}-\mathrm{K}$ diagram $\left(\mathrm{A}=\mathrm{Al}_{2} \mathrm{O}_{3}\right.$; $\mathrm{CN}=\mathrm{CaO}^{*}+\mathrm{Na}_{2} \mathrm{O} ; \mathrm{K}=\mathrm{K}_{2} \mathrm{O}$ ), where few samples of weathered rocks are clustered along the left-hand side of the K-feldspar-plagioclase join (Nesbitt and Young 1984). The Pomburna sandstones plot close to granite-TTG parallel to the A-CN line (figure 10A) and define a non-steady state weathering trend towards the 'A' join. This non-steady state weathering indicates balanced rates of chemical weathering and erosion, which produces compositionally similar sediments over a long period (Nesbitt et al. 1997). The A-CN-K plot depicts the scatter of points near the ACN edge towards the smectite composition, which suggests moderate weathering (figure 10A). The siliciclastic rocks of the present study lie along a trend line parallel to $\mathrm{A}-\mathrm{CN}$ axis emerging from granodiorite, granite and adamelite as a potential source reaching up to the smectite stability zone. The $\mathrm{A}-\mathrm{CN}-\mathrm{K}$ diagram indicates that the samples were generated from a TTG and minor mafic-ultramafic source rock of the upper continental crust affected by moderate intensity of chemical weathering (Madhavaraju et al. 2016). Petrography study further confirm that the presence of plagioclase and alkali-feldspar in almost similar proportions, at places plagioclase is more of $\mathrm{K}$-feldspar indicates that the main sources of these rocks are of TTG-granitic composition.

Similarly, sedimentary rocks which show higher ICV (>1) (tables 3 and 4) are compositionally immature with the first cycle of sediments deposited in tectonically active settings. Whereas, those with ICV $<1$ are compositionally mature and are deposited in a tectonically quiescent or cratonic environment (Van de Kamp and Leake 1985; Cox et al. 1995; Perri et al. 2012). As weathering progresses, ICV values decreases due to conversion of feldspar to Al-bearing clay. Thus variability in ICV values is mainly due to variation in source rock composition and difference in weathering (Cox et al. 1995; Potter et al. 2005). The ICV values of Pomburna sandstone vary from 0.3 to 1.8 $($ mean $=0.95)$. On the basis of average ICV values, it can be interpreted that sediments of study area are compositionally mature and deposited in tectonically quiescent settings, i.e., passive margins (Armstrong-Altrin et al. 2015). Therefore, wide range of CIA and average ICV values of Pomburna sandstones probably indicate that the sediment originated from mixed source under non-steady state and moderate to high degree weathering conditions (figure 10B).

$\mathrm{Th} / \mathrm{U}$ vs. Th bivariant plot can also be used to understand the source area weathering, as surface-weathering process leads to elevate the ratio between $\mathrm{Th}$ and $\mathrm{U}$ to above average $\mathrm{UCC}$ value (figure $8 \mathrm{~A}$ ) ( $\mathrm{Th} / \mathrm{U}=3.8$; Taylor and McLennan 1985) due to the oxidation of $\mathrm{U}^{4+}$ to the more soluble $\mathrm{U}^{6+}$. Th/U ratio above 3.8 is expected to be indicative of weathering history (McLennan et al. 1993; Zaid 2015; Periasamy and Venkateshwarlu 2017). The Th/U ratios of the Pomburna sandstone $(8.0, n=14)$ (tables 4 and 5$)$, indicate a moderate degree of chemical weathering.

Intensive chemical weathering and diagenesis often leaches $\mathrm{Sr}$ compared to $\mathrm{Rb}$ (Nesbitt and Young 1982). This leads to increase in $\mathrm{Rb} / \mathrm{Sr}$ ratio and high ratios are indicative of strong 
weathering (McLennan et al. 1993). The Rb/Sr ratios of the Pomburna sandstones (2.34) are higher than the average post-Archaean Australian shale (0.80; Taylor and McLennan 1985). These high $\mathrm{Rb} / \mathrm{Sr}$ and $\mathrm{Th} / \mathrm{U}$ ratios suggest moderate to strong weathering in the source area.

The $\mathrm{K}_{2} \mathrm{O} / \mathrm{Na}_{2} \mathrm{O}$ ratio increases with weathering due to more labile nature of plagioclase relative to K-feldspars (Nesbitt and Young 1984). Thus the $\mathrm{K}_{2} \mathrm{O} / \mathrm{Na}_{2} \mathrm{O}$ values of less than one in some samples with mature quartz-rich composition (high $\mathrm{SiO}_{2}$ ), are related to a source that was dominated by less evolved plagioclase-rich rocks. On the $\mathrm{A}-\mathrm{CN}-\mathrm{K}$ diagram maximum samples plot along a trend very near to the $\mathrm{A}-\mathrm{CN}$ join and seems to be derived from a source dominated by TTG (figure 10A). Possibly most of the sediment supply was from east where TTG and granite are the main rock types with lesser mafic-ultramafics (figure 2). The petrographic study provides important information on the nature of source area. The presence of inversion textures (rounder but poorly to well sorted bimodal grains) in Pomburna sandstone indicate multiple sources for these rocks (Folk 1974).

Hydraulic sorting can significantly influence the chemical composition of terrigenous sediments (e.g., Garcia et al. 2004; Armstrong-Altrin 2009), and exert controls on the distribution of some trace elements (e.g., Th, U, Zr, Hf and $\mathrm{Nb}$ ). Trace element ratios such as $\mathrm{Th} / \mathrm{Sc}, \mathrm{Th} / \mathrm{Co}$, and $\mathrm{Th} / \mathrm{Cr}$ are significantly different in mafic and felsic source rocks (Cullers 2000). McLennan et al. (1993) used a Th/Sc vs. $\mathrm{Zr} / \mathrm{Sc}$ plots to distinguish the contrasting effects of source composition and sedimentary processes on the composition of clastic sedimentary rocks. The relationship between $\mathrm{Th} / \mathrm{Sc}$ and $\mathrm{Zr} / \mathrm{Sc}$ ratios can be used to infer the recycling of sediments as well as the source rocks (Sharma et al. 2013). Th/Sc vs. Zr/Sc plot of McLennan et al. (1993) shows highly fractionated ratios and follow trend-1 showing direct contribution from primary source rocks and one sample follow trend-2, i.e., recycling of sediments (figure 8B). Similarly, the some sandstones plot in the field sub-parallel to trend 1 near the Proterozoic sandstones (Condie 1993), suggesting compositional homogeneity and minimal influence of sorting by heavy minerals. In general, the results suggest that the Pomburna sandstones are influenced by hydraulic sorting and indicate high maturity.

\subsection{Provenance}

Several studies have shown that the chemical compositions of clastic rocks are significantly controlled by plate tectonic settings of their provenances, and consequently clastic rocks from different tectonic settings possess terrain-specific geochemical signatures (Bhatia 1983; Roser and Korsch 1988). Roser and Korsch (1988) used major oxides as variables and established major element discriminant functions to discriminate four major provenances field namely felsic, mafic, intermediate and quartzose recycled, which are frequently used by many researchers to identify the provenance of terrigenous sediments (Hofer et al. 2013; Khanchuk et al. 2013; Vdacny et al. 2013) and to reflect the source rock composition (Shadan and Hosseini-Barzi 2013).

Discriminant functions used by Roser and Korsch (1988) are used for Pomburna sandstone. The discriminant functions (DF-1 and DF-2) are calculated using the following formulae:

$$
\begin{aligned}
\text { DF- } 1= & \left(-1.773 \mathrm{TiO}_{2} \%\right)+\left(0.607 \mathrm{Al}_{2} \mathrm{O}_{3} \%\right) \\
& +\left(0.76 \mathrm{Fe}_{2} \mathrm{O}_{3} \text { Total } \%\right) \\
& +\left(-1.5 \mathrm{MgO}_{0}\right)+(0.616 \mathrm{CaO} \%) \\
& +\left(0.509 \mathrm{Na}_{2} \mathrm{O} \%\right)-\left(1.224 \mathrm{~K}_{2} \mathrm{O} \%\right) \\
& +(-9.09), \\
\text { DF-2 }= & \left(0.445 \mathrm{TiO}_{2} \%\right)+\left(0.07 \mathrm{Al}_{2} \mathrm{O}_{3} \%\right) \\
& +\left(-0.25 \mathrm{Fe}_{2} \mathrm{O}_{3} \text { Total } \%\right) \\
& +\left(3-1.142 \mathrm{MgO}_{0}\right)+(0.438 \mathrm{CaO} \%) \\
& +\left(1.475 \mathrm{Na}_{2} \mathrm{O} \%\right)+\left(-1.426 \mathrm{~K}_{2} \mathrm{O} \%\right) \\
& +(-6.861)
\end{aligned}
$$

This discriminant function diagram favours a felsic to intermediate igneous rocks with subordinate mature polycyclic continental sedimentary rocks as a source for Pomburna sandstone (Bhatia 1983; Roser and Korsch 1986). This also suggests that the source area for the sandstones were derived from quartz rich or recycled sources, which is consistent with the bivariate plot of $\mathrm{Al}_{2} \mathrm{O}_{3} / \mathrm{TiO}_{2}$ vs. $\mathrm{SiO}_{2}$ (figure $7 \mathrm{~A}$ ). The $\mathrm{K}_{2} \mathrm{O}$ and $\mathrm{Rb}$ contents in terrigenous sediments are sensitive to sedimentary recycling processes and have been widely used as indicators for source composition (ArmstrongAltrin et al. 2012; Tao et al. 2013). In addition; certain trace element ratios also support a silicic source area of Pomburna sandstones. The $\mathrm{Co} / \mathrm{Th}$ (1.56), $\mathrm{Cr} / \mathrm{Th}$ (5.7) and $\mathrm{Cr} / \mathrm{Zr}$ (0.43) ratios of the sandstones (table 3 ) are lower than the UCC (1.7, 
8.8 and 0.48 , respectively), indicating contribution of sediments from felsic sources. Further, $\mathrm{Th} / \mathrm{Sc}$ (2.1) ratios of the sandstones are much higher than the UCC (0.75), indicating contribution from felsic sources (figure $8 \mathrm{~A}$ ).

On La/Sc vs. Th/Co bivariate diagram sandstone samples plot near to silicic rock provenance composition (figure $7 \mathrm{~B}$ ). Furthermore, the $\mathrm{La} / \mathrm{Th}$ vs. Hf bivariate (figure 7C; Floyd and Leveridge 1987) and $\mathrm{V}-\mathrm{Ni}-\mathrm{Th}^{*} 10$ (figure 11A; Bracciali et al. 2007) and La-Th-Sc (Condie 1993; Roser 2000; Absar and Sreenivas 2015) ternary diagrams also suggest that Somanpalli Group sandstone of Pomburna area are derived from felsic and mafic source. This is further supported by presence of felsic source area by low concentration of $\mathrm{Cr}$ and $\mathrm{Ni}$. Felsic provenance for Somanpalli Group is further supported by the $\mathrm{TiO}_{2}$ and $\mathrm{Ni}$ bivariate plot and $\mathrm{Ni}$ vs. Cr bivariate diagram where present samples plot in the post-Archaean field (figure 11C) and suggest that the felsic component was dominant in the source area of the Pomburna sandstone. The $(\mathrm{Gd} / \mathrm{Yb}) \mathrm{CN}$ ratio also document the nature of source rocks and the composition of the continental crust (Taylor and McLennan 1985; Nagarajan et al. 2007). On $\mathrm{Eu} / \mathrm{Eu}^{*}$ vs. (Gd/Yb)CN diagram (figure 11D), the Pomburna sandstones plot in the post-Archaean field and near to PAAS value, which suggest that the post-Archaean felsic rocks could be the source rocks for the Somanpalli Group.

Rare earth elements (REE) are most widely used as indicator of the source rock composition, because they are virtually insoluble and immobile during sedimentary processes and preserve the signature of the source rock (Taylor and McLennan 1985; Cullers 1995; Armstrong-Altrin et al. 2015). REE patterns and the size of the Eu anomaly are also used to study the sources of sedimentary rocks (Taylor and McLennan 1985). Generally, low LREE/HREE ratios and small/absence of $\mathrm{Eu}$ anomalies are indicative of basic rock source, whereas higher ratio $(\mathrm{La} / \mathrm{Y})$ and negative $\mathrm{Eu}$ $\left(\mathrm{Eu} / \mathrm{Eu}^{*}\right)$ anomaly indicates the silicic igneous rock sources and marine depositional environments (Cullers 1994; Pandey and Parcha 2017) (figure 9). The samples of the Pomburna sandstones show high ratio of LREE/HREE and negative Eu anomaly (figure 9B), which supports the silicic rock source and marine depositional environment. For comparison, average REE patterns of study area are also included along with other tectonic setting data in figure $9(\mathrm{C})$. The chondrite normalized
REE patterns for the study area are comparable to average REE pattern other tectonic setting taken from published literature (Bhatia 1985; Bhatia and Cook 1986; Kutterolf et al. 2008). The REE pattern suggests that the samples from the Pomburna area are mainly derived from an old upper continental crust composed chiefly of felsic components with minor mafics. Similarly, in the $\mathrm{Eu} / \mathrm{Eu}^{*}$ and $\mathrm{Th} / \mathrm{Sc}$ diagram (figure 12A; Cullers and Podkovyrov 2000), sandstones of study area plotted in between the average values of granite and granodiorite source.

Based on petrographic study, sandstone of study area are characterised as medium to coarse grained, moderately sorted and moderately matured nature are indicating first cycle sediments transported to a longer distance or sediments might have supplied from recycled source (figure 4C-F) (Amireh 1991; Al-Habri and Khan 2008). However, the textural and mineralogical features as high proportion of quartz, the dominance of K-feldspar over the more chemically unstable plagioclase, unstrained monocrystalline quartz grains, polycrystalline quartz grains composed of three or more crystals with straight to slightly curved intercrystalline boundaries, etc., indicate a weathered crystalline granitic source terrain (Pettijhon 1984; Roser et al. 1996; Zaid 2015).

The collective petrographic and geochemical observations suggest that the Pomburna sandstones are derived from felsic with minor mafic source rock of stable continental areas and deposited in passive continental margin.

Field observations show the existence of igneous bodies such as granite, dioritic rocks in nearby Somnur and Po Gutta Formation. The uplifted shoulders of this rift may have acted as the proximal source area for these sediments. Our geochemical results along with petrographical outcomes are consistent with the idea that the Somnur and Po Gutta Formation in this area were deposited on the trailing edge margin (passive continental margin) of a post-rift basin.

\subsection{Implication for tectonic setting}

Many authors have successfully established the tectonic environment using the proportions of frame work grains by petrographic studies (Dickinson and Suczek 1979; Taylor and McLennan 1985; Periasamy and Venkateshwarlu 2017). The frame work grain properties of quartz and feldspar of studied samples are consistent with those of 

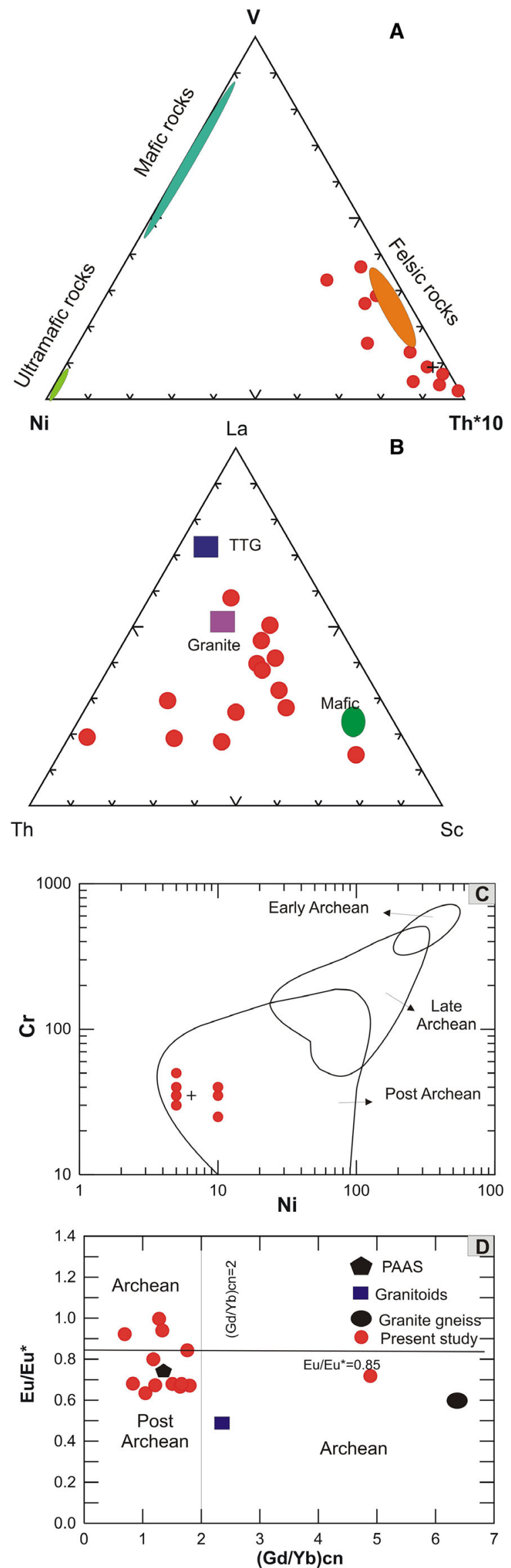

sediments deposited in a passive continental margin (e.g., Zaid 2015, 2017). Pomburna sandstones that fall within the passive continental block are chiefly derived from exposed shield areas of Bastar craton. The Qt-F-L and Qm-F-Lt diagrams (Dickinson and Suczek 1979) for the Pomburna sandstones reveal a recycled-orogen provenance and a craton-interior provenance (figure 5B). Within recycled orogens, sediment sources are dominantly derived from tectonic settings, where stratified rocks are deformed, uplifted and eroded (Dickinson and Suczek 1979; Dickinson 1985). As pointed out by Dickinson et al. (1983), sandstones plotting in craton-interior field are mature sandstones derived from relatively low-lying granitoid and gneissic sources, supplemented by recycled sands from associated platform or passive margin basins. The detrital modal compositions of sandstones are plotted in the $\mathrm{Q}-\mathrm{F}-\mathrm{L}$ diagram (figure 12B; Yerino and Maynard 1984), which indicates that these sandstones are related to trailingedge margin.

The tectonic setting discriminant diagrams proposed by many authors can provide reliable results for siliciclastic rocks because they are not too much affected by post-depositional weathering/ metasomatism/metamorphism (McLennan et al. 1993). Bhatia (1983), Bhatia and Cook (1986), Roser and Korsch (1986), Peterson (2009), Linhua et al. (2012), Sari and Koca (2012), Jianghai et al. (2012), Jorge et al. (2013), Kassi et al. (2015); Periasamy and Venkateshwarlu (2017), Sun et al. (2012), Pandey and Parcha (2017).

Bhatia (1983) and Roser and Korsch (1986) proposed tectonic setting discrimination fields for sedimentary rocks by using $\mathrm{SiO}_{2}$ content and $\mathrm{K}_{2} \mathrm{O} / \mathrm{Na}_{2} \mathrm{O}$ ratios to identify the tectonic setting of unknown basins. The present sandstones are

Fig. 11. (A) Nature of provenance shown by V-Ni-Th*10 ternary diagram (after Bracciali et al. 2007). Shaded area represents composition of the felsic, mafic, and ultramafic rocks. The Somanpalli Group sandstones plot near felsic source rocks. (B) La-Th-Sc ternary diagram indicating felsic to intermediate source rocks. Various source end members are also plotted for reference (TTG; G, granite; A, andesite; B, basalt, after Condie 1993; Roser 2000). (C) Ni-Cr bivariate plot after McLennan et al. (1993), where majority of the samples plot near the acidic source field; (D) Plot of $\mathrm{Eu} / \mathrm{Eu}^{*}$ vs. $(\mathrm{Gd} / \mathrm{Yb}) \mathrm{CN}$ for the samples of the Pomburna sandstone. Fields showing post Archaean and Archaean are after McLennan and Taylor (1991). 

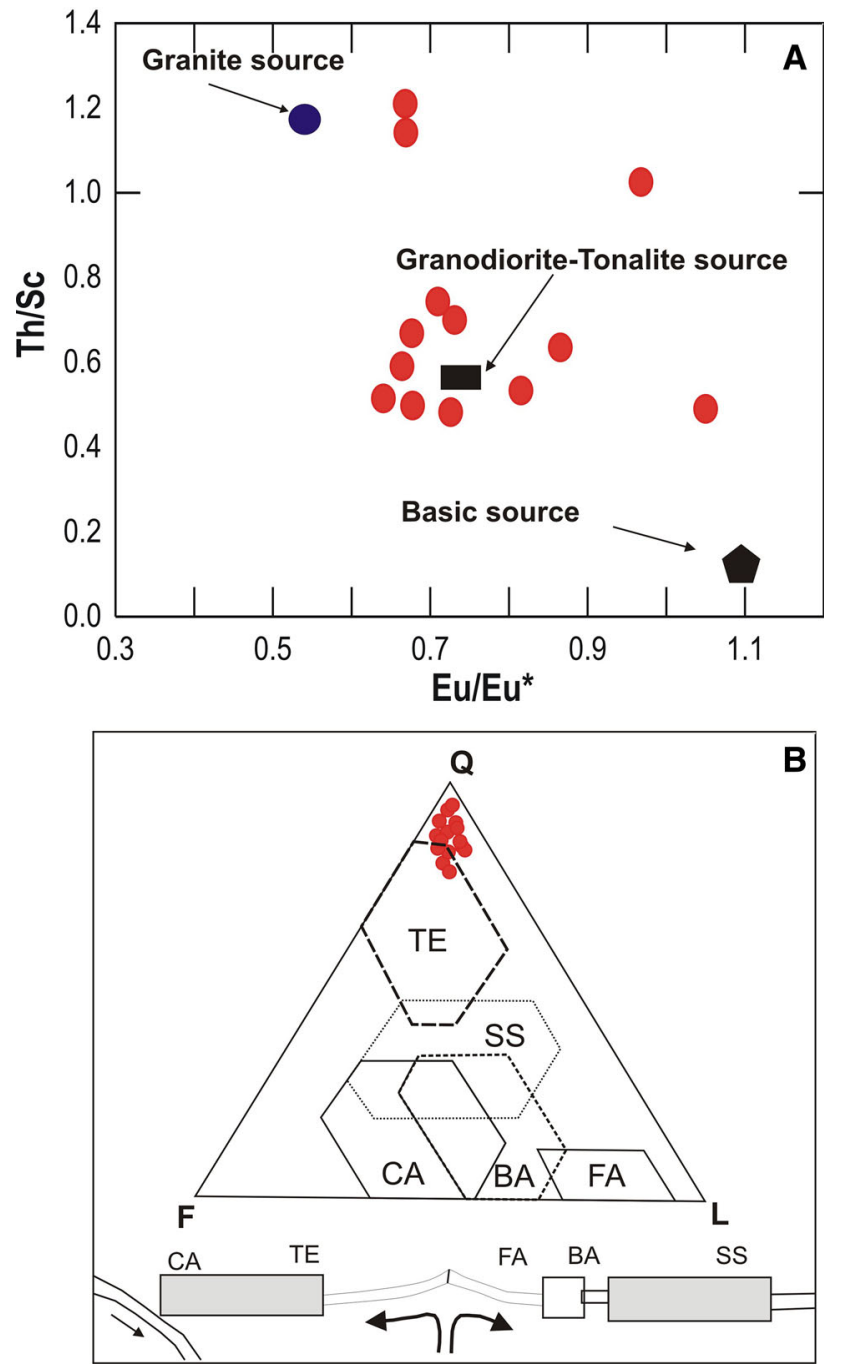

Figure 12. (A) Provenance signature discrimination diagram of sandstone of Somanpalli Group samples plotted on $\mathrm{K}_{2} \mathrm{O} / \mathrm{Na}_{2} \mathrm{O}$ vs. $\mathrm{SiO}_{2}$ and $\mathrm{SiO}_{2} / \mathrm{Al}_{2} \mathrm{O}_{3}$ vs. $\mathrm{K}_{2} \mathrm{O} / \mathrm{Na}_{2} \mathrm{O}$ after Roser and Korsch (1988) showing TTG and granite source. (B) Q-F-L tectonic provenance diagram of sandstone of Somanpalli after Yerino and Maynard (1984), maximum plot near the TE field. TE, trailing edge (also called passive margin); SS, strike-slip; CA, continentalmargin arc; BA, backarc to island arc; FA, forearc to island arc.

characterized by high $\mathrm{K}_{2} \mathrm{O} / \mathrm{Na}_{2} \mathrm{O}$ ratios (0.04 to 2.6 with an average of 0.71 ), which is typical for clastic rocks deposited in a passive continental margin (Roser and Korsch 1986) (figure 13A). These tectonic setting discrimination diagrams are still extensively used by many researchers to infer the tectonic setting of ancient basins (Saeed et al. 2011 and references there in). However, on the $\mathrm{K}_{2} \mathrm{O} / \mathrm{Na}_{2} \mathrm{O}$ vs. $\mathrm{SiO}_{2}$ and $\mathrm{K}_{2} \mathrm{O} / \mathrm{Na}_{2} \mathrm{O}$ vs. $\mathrm{SiO}_{2} / \mathrm{Al}_{2} \mathrm{O}_{3}$ tectonic discrimination diagram, most of the sandstone samples of Pomburna area fall in the passive margin field (figure 13A, B), which suggest quartz-rich sediments derived from adjacent continental stable or rifted margin. Chemical analyses of the Pomburna sandstone are plotted on tectonic discriminant diagrams $\left(\mathrm{K}_{2} \mathrm{O} / \mathrm{Na}_{2} \mathrm{O}\right.$ vs. $\mathrm{SiO}_{2} ; \quad \mathrm{SiO}_{2} / 20-\mathrm{K}_{2} \mathrm{O}+\mathrm{Na}_{2} \mathrm{O}$ $\mathrm{TiO}_{2}+\mathrm{Fe}_{2} \mathrm{O}_{3}+\mathrm{MgO} ; \mathrm{Fe}_{2} \mathrm{O}_{3}+\mathrm{MgO}$ vs. $\mathrm{TiO}_{2}$ suggested by Kroonenberg (1994); figure 13C-E), showing passive margin (PM) setting, which indicates that the sediments are derived from stable continental blocks and deposited in several types of basins including rift basins (Roser and Korsch 1986). This result is further supported by their low $\left(\mathrm{MgO}+\mathrm{Fe}_{2} \mathrm{O}_{3}\right), \mathrm{TiO}_{2}$ and $\mathrm{Al}_{2} \mathrm{O}_{3} / \mathrm{SiO}_{2}$ ratio of the sandstone, $\left(\mathrm{Fe}_{2} \mathrm{O}_{3}+\mathrm{MgO}\right)$ vs. $\mathrm{Al}_{2} \mathrm{O}_{3} / \mathrm{SiO}_{2}$ diagram suggested by Bhatia (1983) (figure 13C-E), show plot of maximum samples in passive margin tectonic field. Passive margin sediments are largely quartz-rich, derived from plate interiors or stable continental margins. Bhatia (1985) argued that the sedimentary rocks deposited on passive margins are characterized by a pronounced negative Eu anomaly on chondrite-normalized patterns. The observed negative Eu anomaly in the chondrite normalized REE patterns in the Pomburna sandstones supports a passive margin tectonic setting (figure 9).

The tectonic setting discrimination diagrams proposed by Bhatia (1983) and Roser and Korsch (1986) for clastic sediments were used in many studies to identify the tectonic setting of unknown basins (Zaid 2017). Many researchers cautioned against the use of these previously proposed discrimination diagrams (e.g., Armstrong-Altrin and Verma 2005). Recently, Verma and ArmstrongAltrin (2013) proposed two discriminant-function based major-element diagrams for the tectonic discrimination of siliciclastic sediments from three main tectonic settings; island or continental arc, continental rift and collision, that have been created for the tectonic discrimination of high-silica $\left(\mathrm{SiO}_{2}\right.$ adj $\left.=63-95 \%\right)$ and low-silica rocks $\left(\mathrm{SiO}_{2}\right.$ adj $=35-63 \%$ ). These diagrams were used in present studies to discriminate the tectonic setting of a source region, based on sediment geochemistry (Armstrong-Altrin et al. 2015). According to the high-silica diagram (figure 13B), all samples of the study area are plotted in mixed rift and arc field. The result obtained from this discriminantfunction-based multi-dimensional diagram provides a good evidence for the PG valley tectonic system, which is consistent with the general geology of Eastern Belt of PG valley shouldering with Bastar craton. 

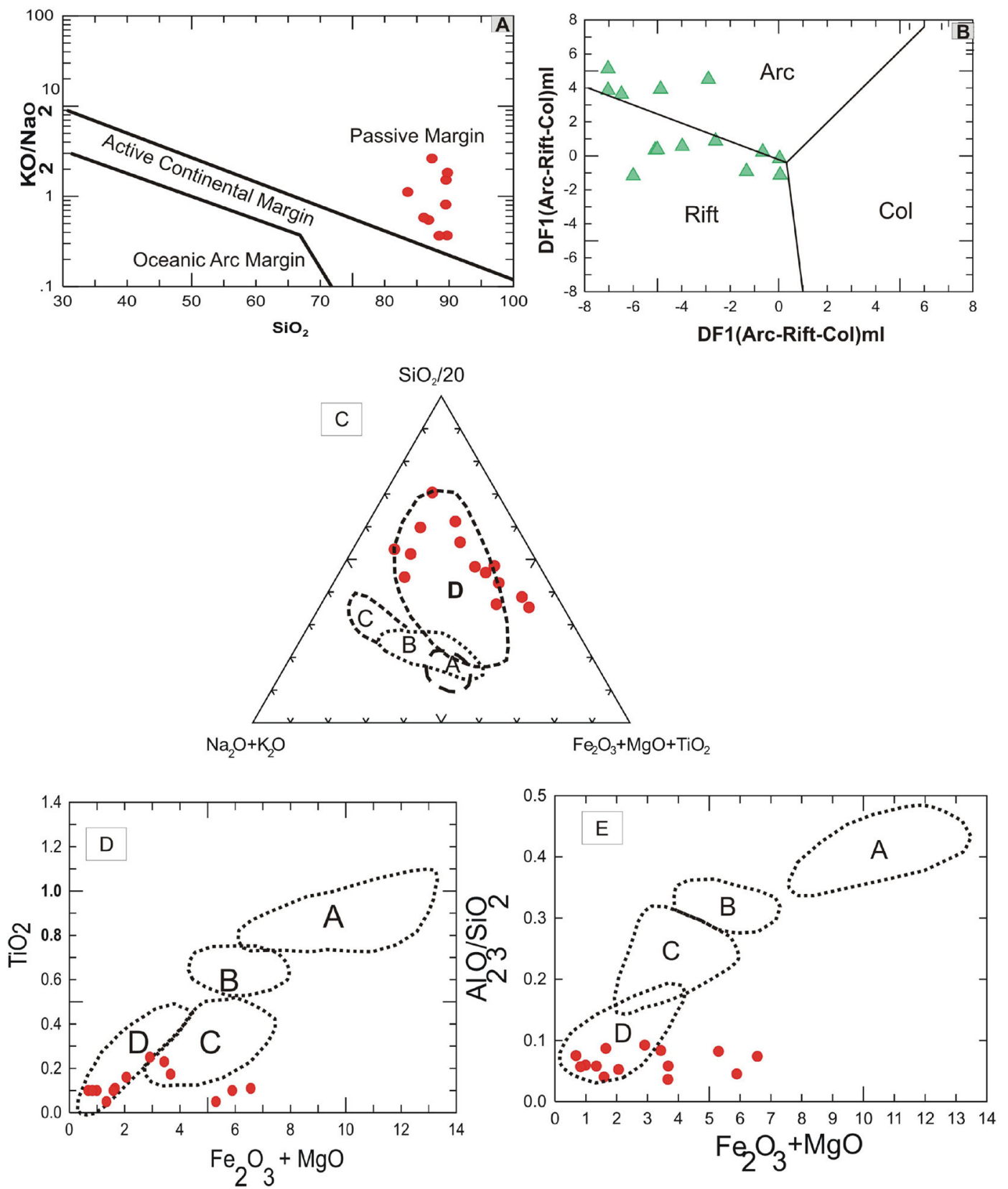

Figure 13. Tectonic discrimination diagrams for sandstone of Pomburna area based on major oxides of the sandstone: (A) after Roser and Korsch (1988) showing passive margin tectonic setting. (B) New discriminant-function multi-dimensional diagram proposed by Verma and Armstrong-Altrin (2013) for high silica clastic sediments from three tectonic settings (arc, continental rift, and collision). The subscript $\mathrm{m} 1$ in DF-1 and DF-2 represents the high-silica diagram based on logeratios of major-elements. The discriminant function equations are DF-1 (Arc-Rift- $\mathrm{Col})_{\mathrm{m} 1}=(-0.263 \times \ln (\mathrm{TiO} 2 / \mathrm{SiO} 2) \mathrm{adj})+$ $\left(0.604 \times \ln \left(\mathrm{Al}_{2} \mathrm{O}_{3} / \mathrm{SiO}_{2}\right) \mathrm{adj}\right)+\left(-1.725 \times \ln \left(\mathrm{Fe}_{2} \mathrm{O}_{3}^{\mathrm{t}} / \mathrm{SiO}_{2}\right) \operatorname{adj}\right)+\left(0.660 \times \ln \left(\mathrm{MnO} / \mathrm{SiO}_{2}\right) \operatorname{adj}\right)+(2.191 \times \ln (\mathrm{MgO} / \mathrm{SiO} 2) \operatorname{adj})+$ $\left(0.144 \times \ln \left(\mathrm{CaO} / \mathrm{SiO}_{2}\right) \mathrm{adj}\right)+\left(-1.304 \times \ln \left(\mathrm{Na}_{2} \mathrm{O} / \mathrm{SiO}_{2}\right) \mathrm{adj}\right)+\left(0.054 \times \ln \left(\mathrm{K}_{2} \mathrm{O} / \mathrm{SiO}_{2}\right) \mathrm{adj}\right)+\left(-0.330 \times \ln \left(\mathrm{P}_{2} \mathrm{O}_{5} / \mathrm{SiO} 2\right) \mathrm{adj}\right)+$ 1.588. DF-2 $(\mathrm{Arc}-\mathrm{Rift}-\mathrm{Col})_{\mathrm{m} 1}=\left(-1.196 \times \ln \left(\mathrm{TiO}_{2} / \mathrm{SiO}_{2}\right) \mathrm{adj}\right)+\left(1.604 \times \ln \left(\mathrm{Al}_{2} \mathrm{O}_{3} / \mathrm{SiO}_{2}\right) \operatorname{adj}\right)+\left(0.303 \times \ln \left(\mathrm{Fe}_{2} \mathrm{O}_{3}^{\mathrm{t}} / \mathrm{SiO} 2\right) \operatorname{adj}\right)$ $+\left(0.436 \times \ln \left(\mathrm{MnO} / \mathrm{SiO}_{2}\right) \mathrm{adj}\right)+\left(0.838 \times \ln \left(\mathrm{MgO} / \mathrm{SiO}_{2}\right) \operatorname{adj}\right)+\left(-0.407 \times \ln \left(\mathrm{CaO} / \mathrm{SiO}_{2}\right) \operatorname{adj}\right)+\left(1.021 \times \ln \left(\mathrm{Na}_{2} \mathrm{O} / \mathrm{SiO} 2\right) \operatorname{adj}\right)+$ $\left(-1.706 \times \ln \left(\mathrm{K}_{2} \mathrm{O} / \mathrm{SiO}_{2}\right) \mathrm{adj}\right)+\left(-0.126 \times \ln \left(\mathrm{P}_{2} \mathrm{O}_{5} / \mathrm{SiO}_{2}\right) \mathrm{adj}\right)-1.068$. (C) Ternary plot after Kroonenberg $(1994) .(\mathbf{D}-\mathbf{E})$ bivariate plot after Bhatia (1983) showing passive margin tectonic setting. A: oceanic island arc; B: continental island arc; C: active continental margin; D: passive margin.

Additionally, except for the above discussed discrimination diagrams, high chemical maturity of the sandstones is revealed by their high ICV values (mean $=0.95)$, in combination with the recycled orogenic provenance (figure 5B), which also supports their formation in a tectonically stable environment. 


\section{Conclusions}

The Pomburna area in northern extension of Somanpalli Group in the Eastern Belt of PG Valley, central India exposes mainly sandstones alternating with limestone and shale beds referring to shallow warm and marine conditions. On the basis of present studies following conclusions can be drawn:

1. Chemical analyses revealed that sandstones have high $\mathrm{SiO}_{2}$ and low $\mathrm{Fe}_{2} \mathrm{O}_{3}, \mathrm{MgO}, \mathrm{MnO}$ values, which are consistent with the modal data. Also, sandstone samples are enriched in most trace elements such as $\mathrm{U}, \mathrm{Th}, \mathrm{Nb}$ and $\mathrm{Zr}$ and depleted in $\mathrm{Sr}, \mathrm{Ba}$ and $\mathrm{Ta}$.

2. The geochemical data interpretation on the basis discriminate function diagram (Roser and Korsch 1986) reveals the source material was deposited in passive continental margin setting.

3. Trace element (La/Sc vs. Th/Co) and $\mathrm{La}_{-}-\mathrm{Th}-$ Sc indicate that these sandstones were derived from felsic and mafic source rocks.

4. Erosion of the pre-rift and syn-rift sedimentary substratum and erosion of metamorphic basement of Western Bastar craton in later stages were the main sources for the Somnur and Po Gutta Formation detritus.

5. The tectonic setting discrimination diagrams support a passive continental margin or intraplate environment for the sandstones of Pomburna area.

6. The high CIA values of the sandstones (6084 ) indicate high degree of weathering, which is further supported by the high CIW values (75-87) implying moderate to intensive weathering of the source, which may reflect warm and humid paleoclimatic condition in source area.

7. The studied sandstones have quartzo-lithic and quartzo-sepetro facies pointing to derivation from a recycled orogen (uplifted shoulders of rifts and trailing edge provenance) and cratonic tectonic provenance. These sandstones are predominantly derived from a felsic source with a component from pre-existing metamorphic and sedimentary rocks, which are all located in the basement along western fringe of Bastar craton. This might have exposed in Palaeoproterozoic (initiation of rifting Orogeny) and continued until the Mesoproterozoic time and supplied sediments to Pomburna area.

\section{Acknowledgements}

Authors thank Shri M Raju, Director General, Geological Survey of India, Kolkata for granting permission to publish this paper. The authors are thankful to Shri B Khuntia, S Lenka, R Barik, and Kaushik Shree, Geologists, for their active association and cooperation during the fieldwork. Authors express their sincere gratitude to Prof. N V C Rao, Chief Editor of JESS for his help and encouragement during review process. The authors acknowledge the personnel of XRF, ASS, and ICP-MS of Chemical Laboratory, GSI, CR for providing quality chemical analysis. The authors also acknowledge GSI's in house reviewers, especially Shri Ananad Agasty, Director, Publication Division, CR, and Shri J K Naik, SU: MH for their important suggestions. Authors highly acknowledge two anonymous reviewers for their critical review, constructive and thoughtful suggestions, which helped a lot in improving this manuscript.

\section{References}

Absar N, Nizamudheen B M and Augustine S 2016 Petrography, clay mineralogy and geochemistry of clastic sediments of Proterozoic Bhima Group, Eastern Dharwar Craton, India: Implications for provenance and tectonic setting; J. Appl. Geochem. 18(3) 237-250.

Absar N and Sreenivas B 2015 Petrology and geochemistry of greywackes of the $\sim 1.6 \mathrm{Ga}$ Middle Aravalli Supergroup, northwest India: Evidence for active margin processes; Int. Geol. Rev. 57(2) 134-158, https://doi.org/10.1080/ 00206814.2014 .999355$.

Absar N, Raza M, Roy M, Naqvi S M and Roy A K 2009 Composition and weathering conditions of Paleoproterozoic upper crust of Bundelkhand craton, central India: From geochemistry of clastic sediments of $1.9 \mathrm{Ga}$ Gwalior Group; Precamb. Res. 168 313-329, https://doi.org/10. 1016/j.precamres.2008.11.001.

Al-Habri O A and Khan M M 2008 Provenance, diagenesis, tectonic setting and geochemistry of Tawil sandstone Lower Devonian in central Saudi Arabia; J. Asian Earth Sci. Bull. 33 278-287.

Amarasinghe U, Chaudhuri A, Collins A S, Deb G and Sarbani Patranabis-Deb 2015 Evolving provenance in the Proterozoic Pranhita-Godavari Basin, India; Geosci. Front. 6(3) 453-463.

Amireh B S 1991 Mineral composition of the CambrianCretaceous Nubian series of Jordon: Provenance, tectonic setting and climatological implication; Sedim. Geol. 71 99-119.

Armstrong-Altrin J S 2009 Provenance of sands from Cazones, Acapulco, and Bahía Kino beaches, Mexico; Rev. Mex. Cienc. Geol. 26(3) 764-782.

Armstrong-Altrin J S and Verma S P 2005 Critical evaluation of six tectonic setting discrimination diagrams 
using geochemical data of Neogene sediments from known tectonic settings; Sedim. Geol. 177 115-129.

Armstrong-Altrin J S, Lee Y I, Verma S P and Ramasamy S 2004 Geochemistry of sandstones from the Upper Miocene Kudankulam Formation, southern India: Implications for provenance, weathering, and tectonic setting; J. Sedim. Res. 74(2) 285-296.

Armstrong-Altrin J S, Lee Y I, Kasper-Zubillaga J J, Carranza-Edwards A, Garcia D, Eby N, Balaram V and Cruz-Ortiz N L 2012 Geochemistry of beach sands along the Western Gulf of Mexico, Mexico: Implication for provenance; Chem. Erde Geochem. 72 345-362.

Armstrong-Altrin J S, Machain-Castillo M L, Rosales-Hoz L, Carranza-Edwards A, Sanchez-Cabeza J A and RuízFernández A C 2015 Geochemistry of deep sea sediments from the southwestern Gulf of Mexico, Mexico: Implication for depositional environment; Cont. Shelf Res. 95 $15-26$.

Basumallick S 1967 Problems of the Purana stratigraphy of the Godavari Valley with special reference to the type area in Warangal district, Andhra Pradesh, India; Quat. J. Geol. Min. Metal. Soc. India 39 115-127.

Bhatia M R 1983 Plate tectonics and geochemical composition of sandstones; J. Geol. 91 611-627.

Bhatia M R 1985 Plate tectonics and geochemical composition of sandstones: A reply; J. Geol. 93 85-87.

Bhatia M R and Cook K A W 1986 Trace element characteristics of graywackes and tectonic setting discriminant of sedimentary basins; Contrib. Mineral. Petrol. 92 181-193.

Blatt H, Middleton G and Murray R 1972 Origin of Sedimentary Rocks: Englewood Cliffs; Prentice Hall, New Jersey, $634 \mathrm{p}$.

Bracciali L, Marroni M, Pandolfi L and Rocchi S 2007 Geochemistry and petrography of Western Tethys Cretaceous sedimentary covers (Corsica and Northern Apennines): From source areas to configuration of margins; In: Sedimentary provenance and petrogenesis: Perspectives from petrography and geochemistry (eds) Arribas J, Critelli S and Johnsson M J, Geol. Soc. Am. Spec. Paper 42073 93.

Chakraborty T 1991 Sedimentology of a Proterozoic Era: The Venkatapur sandstone, P.G. Valley, South India; Sedimentology 38 301-322.

Chakraborty T and Chaudhuri A K 1993 Fluvial-aeolian interactions in a Proterozoic alluvial plain: Example from Mancheral Quartzite, Pranhita-Godavari Valley, India; In: Dynamics and Environmental Context of Aeolian Sedimentary Systems (ed.) Pye K, Geol. Soc. London Spec. Publ. 72 127-141.

Chaudhuri A K 1985 Stratigraphy of the Purana Supergroup, Andhra Pradesh; J. Geol. Soc. India 26 301-314.

Chaudhuri A K and Howard J D 1985 Ramgundam sandstone - a middle Proterozoic shoal-bar sequence; J. Sedim. Petrol. 55 392-397.

Chaudhuri A K, Dasgupta S, Bandopadhyay G, Sarkar S, Bandopadhyay P C and Gopalan K 1989 Stratigraphy of the Penganga Group around Adilabad, Andhra Pradesh; J. Geol. Soc. India 34 291-302.

Chaudhuri A K, Deb G K, Deb S P and Sarkar S 2012 Paleogeographic and tectonic evolution of the Pranhita-Godvari valley, central India: A stratigraphic perspective; $A m$. J. Sci. 312 766-815, https://doi.org/10.2475/07.2012.03.
Chaudhuri A K, Deb G K and Deb S P 2015 Conflicts in stratigraphic classification of the Puranas of the PranhitaGodavari Valley: Review, recommendations and status of the 'Penganga' sequence; Geol. Soc. London Memoir 43 $165-183$.

Clift P D, Degnan P J, Hannigan R and Blusztajn J 2000 Sedimentary and geochemical evolution of the Dras forearc basin, Indus suture, Ladakh Himalaya, India; Geol. Soc. Am. Bull. 112 450-466.

Condie K C 1993 Chemical-composition and evolution of the upper continental-crust contrasting results from surface samples and shales; Chem. Geol. 104 1-37.

Conrad J, James R H, Chaudhuri A K, Deb S P, Mukhopadhyay J, Gautam K D and N S J 2011 Constraints on the development of proterozoic basins in central India from ${ }^{40} \mathrm{Ar} /{ }^{39} \mathrm{Ar}$ analysis of authigenic glauconitic minerals; Geol. Soc. Am. Bull. 123 158-167.

Cox R, Lowe D R and Cullers R L 1995 The influence of sediment recycling and basement composition on evolution of mudrock chemistry in the southwestern United States; Geochim. Cosmochim. Acta 59 2919-2940.

Cullers R L 1994 The controls on the major and trace element variation of shales, siltstones, and sandstones of Pennsylvanian-Permian age from uplifted continental blocks in Colorado to platform sediment in Kansas, USA; Geochim. Cosmochim. Acta 58 4955-4972.

Cullers R L 1995 The controls on the major and trace element evolution of shales, siltstones and sandstones of Ordovician to Tertiary age in the Wet Mountain region, Colorado, USA; Chem. Geol. 123(1-4) 107-131.

Cullers R L 2000 The geochemistry of shales, siltstones and sandstones of Pennsylvanian-Permian age, Colorado, USA: Implications for provenance and metamorphic studies; Lithos 51 181-203.

Cullers R L and Podkovyrov V N 2000 Geochemistry of the Mesoproterozoic Lakhandashales in southeastern Yakutia, Russia: Implications for mineralogical and provenance control, and recycling; Precamb. Res. 104 77-93.

Cullers R L 2002 Implications of elemental concentrations for provenance, redox conditions and metamorphic studies of shales and limestones near Pueblo, CO, USA; Chem. Geol. 191 305-327.

Dickinson W R 1985 Interpreting provenance relations from detrital modes of sandstones; In: Provenance of Arenites: NATO Advanced Study Institutes Series (ed.) Zuffa G G, Series C: Math. Phys. Sci., D. Reidel Publishing Company 148 333-361.

Dickinson W R and Suczek C A 1979 Plate tectonics and sandstone composition; AAPG Bull. 63 2164-2182.

Dickinson W R, Beard L S, Brakenridge G R, Evjavec J L, Ferguson R C, Inman K F, Knepp R A, Lindberg F A and Ryberg P T 1983 Provenance of North American Phanerozoic sandstones in relation to tectonic setting; Geol. Soc. Am. Bull. 94 222-235.

Dora M L 2012 Host rock characteristics, control and genesis of copper-barite mineralization in Thanewasna area, Chandrapur district, Maharashtra; RTM University, Nagpur, unpublished Ph.D. Thesis, 220p.

Dora M L and Randive K R 2015 Chloritization along the Thanewasna shear zone, Western Bastar Craton, Central India: Its genetic linkage to $\mathrm{Cu}-\mathrm{Au}$ mineralization; Ore Geol. Rev. 70 151-172. 
Fedo C M, Nesbitt H W and Young G M 1995 Unraveling the effects of potassium metasomatism in sedimentary rocks and paleosoils, with implications for paleoweathering conditions and provenance; Geology 23 921-924.

Floyd P A and Leveridge B E 1987 Tectonic environment of the Devonian Gramscatho basin, south Cornwall: Framework mode and geochemical evidence from turbiditic sandstones; J. Geol. Soc. 144(4) 531-542.

Folk R L 1974 Petrology of Sedimentary Rocks; Hemphill Publishing, Austin, Texas, 159p.

Garcia D, Ravenne C, Maréchal B and Moutte J 2004 Geochemical variability induced by entrainment sorting: Quantified signals for provenance analysis; Sedim. Geol. 171(1-4) 113-128.

Harnois L 1988 The CIW index: A new chemical index of weathering; Sedim. Geol. 55 319-322.

Hofer G, Wagreich M and Neuhuber S 2013 Geochemistry of fine-grained sediments of the Upper Cretaceous to Paleogene Gosau Group (Austria, Slovakia): Implications for paleoenvironmental and provenance studies; Geosci. Front. 4(4) 449-468, https://doi.org/10.1016/j.gsf.2012. 11.009 .

Holland H D 1978 The Chemistry of the Atmosphere and Oceans; Wiley, New York, 351p.

Ingersoll R V and Suczek C A 1979 Petrology and provenance of Neogene sand from Nicobar and Bengal fans, DSDP sites 211 and 218; J. Sedim. Petrol. 49 1217-1228.

Jianghai Y, Yuansheng du, Cawood P A and Yajun X 2012 Modal and geochemical compositions of the lower Silurian clastic rocks in north Qilian, NW china: Implications for provenance, chemical weathering, and tectonic setting; J. Sedim. Res. 82 92-103.

Jorge R C G S, Fernandes P, Rodrigues B, Pereira Z and Oliveira J T 2013 Geochemistry and provenance of the Carboniferous Baixo Alentejo Flysch Group, South Portuguese Zone; Sedim. Geol. 284-285 133-148.

Kassi A M, Grigsby J D, Khan A S and Kasi A K 2015 Sandstone petrology and geochemistry of the OligoceneEarly Miocene Panjgur Formation, Makran accretionary wedge, southwest Pakistan: Implications for provenance, weathering and tectonic setting; J. Asian Earth Sci. 105 192-207.

Khanchuk A I, Nevstruev V G, Berdnikov N V and Nechaev V P 2013 Petrochemical characteristics of carbonaceous shales in the eastern Bureya massif and their preciousmetal mineralization; Russ. Geol. Geophys. 54 627-636.

Kroonenberg S B 1994 Effects of provenance, sorting and weathering on the geochemistry of fluvial sands from different tectonic and climatic environments; Proc. 29th Int. Geol. Cong. A 69-81.

Kutterolf S, Diener R, Schacht U and Krawinkel H 2008 Provenance of the Carboniferous Hochwipfel Formation (Karawanken Mountains, Austria/Slovenia) Geochemistry vs. petrography; Sedim. Geol. 203 246-266.

Lamaskin T A, Dorsey R J and Vervoort J D 2008 Tectonic controls on mudrock geochemistry, Mesozoic rocks of eastern Oregon and western Idaho, USA: Implications for cordilleran tectonics; J. Sedim. Res. 78 765-783, https:// doi.org/10.2110/jsr.2008.087.

Le Bas M J, Le Maitre R W, Streckeisen A and Zanettin B 1986 A chemical classification of volcanic rocks based on the total alkali-silica diagram; J. Petrol. 27(3) 745-750.
Linhua S, Herong G and Song C 2012 Geochemistry of sandstones from the Neoproterozoic Shijia Formation, northern Anhui Province, China: Implications for provenance, weathering and tectonic Setting; Chem. Erde $\mathbf{7 2}$ 253-260.

Madhavaraju J, Erik Ramirez-Montoya E, Monreal R, González-Leon C M, Pi-Puig T, Espinoza-Maldonado I G and Grijalva-Noriega F J 2016 Paleoclimate, paleoweathering and paleoredox conditions of Lower Cretaceous shales from the Mural Limestone, Tuape section, northern Sonora, Mexico: Constraints from clay mineralogy and geochemistry; Rev. Mex. Cienc. Geol. 33(1) 3448.

Mahapatra K C, Tripathy S K and Dora M L 2010 Assessment of copper and associated mineralization in Thanewasna Copper Prospect, Chandrapur District, Maharashtra; Geol. Surv. India Rep., p. 120.

McLennan S M 1989 Rare earth elements in sedimentary rocks: Influence of provenance and sedimentary processes; Rev. Mineral. 21 169-200.

McLennan S M 1993 Weathering and global denudation; J. Geol. 101 295-303.

McLennan S M 2001 Relationships between the trace element composition of sedimentary rocks and upper continental crust; Geochem. Geophys. Geosys. 2 GC000109.

McLennan S M and Taylor S R 1991 Sedimentary rocks and crustal evolution: Tectonic setting and secular Trends; J. Geol. 99 1-21.

McLennan S M, Taylor S R and Eriksson K A 1983 Geochemistry of Archaean shales from the Pilbara Super group, Western Australia; Geochim. Cosmochim. Acta 47(7) 1211-1222.

McLennan S M, Hemming S, McDaniel D K and Hanson G N 1993 Geochemical approaches to sedimentation, provenance and tectonics; In: Processes Controlling the Composition of Clastic Sediments (eds) Johnson M J and Basu A, Geol. Soc. Am. Spec. Paper, pp. 21-40.

McLennan S M, Bock B, Hemming S R, Hurrowitz J A, Lev S M and McDaniel D K 2003 The roles of provenance and sedimentary processes in the geochemistry of sedimentary rocks; In: Geochemistry of Sediments and Sedimentary Rocks: Evolutionary Considerations to Mineral-deposit Forming Environments (ed.) Lentz D R, Geol. Assoc. Canada Geotext 4 7-38.

Mongelli G, Critelli S, Perri F, Sonnino M and Perrone V 2006 Sedimenatry recycling, provenance and paleoweathering from chemistry and mineralogy of Mesozoic continental redbed mudrocks, Peloritani Mountains, southern Italy; Geochem. J. 40 197-209.

Moosavirad S M, Janardhana M R, Sethumadhav M S, Moghadam M R and Shankara M 2011 Geochemistry of lower Jurassic shales of the Shemshak Formation, Kerman Province, Central Iran: Provenance, source weathering and tectonic setting; Chem. Erde 71(3) 279-288.

Mukharjee M K, Jeere D S, Tripathy S K and Singh A K 2007 Thematic mapping of gneiss-granulite terrain, Western Bastar Craton, Chandrapur district, Maharashtra, FSP2004-07; Geol. Surv. India Rec. 140123.

Nagarajan R, Madhavaraju J, Nagendra R, ArmstrongAltrin J S and Moutte J 2007 Geochemistry of Neoproterozoic shales of the Rabanpalli Formation, Bhima Basin, Northern Karnataka, southern India: Implications for 
provenance and paleoredox conditions; Rev. Mex. Cienc. Geol. 24 150-160.

Nagarajan R, Armstrong-Altrin J S, Kessler F L and Jong J 2017 Petrological and geochemical constraints on provenance, paleoweathering, and tectonic setting of clastic sediments from the Neogene Lambir and Sibuti Formation; Sediment Provenance, pp. 123-153.

Naqvi S M and Rogers J J W 1987 Precambrian Geology of India; Oxford University Press, Oxford, 233p.

Nath B N, Kunzendorf H and Pluger W L 2000 Influence of provenance, weathering and sedimentary process on the elemental ratios of the fine-grained fraction of the bedload sediments from the Vembanad Lake and the adjoining continental shelf, southwest coast of India; J. Sedim. Res. 70 1081-1094.

Nesbitt H W and Young G M 1982 Early Proterozoic climates and plate motions inferred from major element chemistry of lutites; Nature 299 715-717.

Nesbitt H W and Young G M 1984 Prediction of some weathering trends of plutonic and volcanic rocks based on thermodynamic and kinetic considerations; Geochim. Cosmochim. Acta 8 1523-1534.

Nesbitt H W and Young G M 1989 Formation and diagenesis of weathering profiles; J. Geol. 97 129-147.

Nesbitt H W and Young G M 1996 Petrogenesis of sediments in the absence of chemical weathering: Effects of abrasion and sorting on bulk composition and mineralogy; Sedimentology 43 341-358.

Nesbitt H W, Fedo C M and Young G M 1997 Quartz and feldspar stability, steady and nonsteady state weathering, and petrogenesis of siliciclastic sands and muds; J. Geol. 105 173-191.

Pandey S and Parcha S K 2017 Provenance, tectonic setting and source-area weathering of the lower Cambrian sediments of the Parahio Valley in the Spiti Basin, India; J. Earth Syst. Sci. 126 27, https://doi.org/10. 1007/s12040-017-0803-5.

Perri F, Critelli S, Cavalcante F, Mongelli G, Dominici R, Sonnino M and De Rosa R 2012 Provenance signatures for the Miocene volcaniclastic succession of the Tufiti di Tusa Formation southern Apennines, Italy; Geol. Mag. 149 423-442.

Periasamy V and Venkateshwarlu M V 2017 Petrography and Geochemistry of Jurassic Sandstones from the Jhuran Formation of Jara dome, Kachchh basin, India: Implications for Provenance and Tectonic setting; J. Earth Syst. Sci. 126 44, https://doi.org/10.1007/ s12040-017-0822-2-72.

Peterson J A 2009 Geochemical provenance of clastic sedimentary rocks in the western Cordillera. Utah, Colorado, Wyoming, and Oregon, MSc thesis, Utah State University.

Pettijhon F J 1984 Sedimentary Rocks; 3rd India CBS Publ. and Dist., 628p.

Potter P E, Maynard J B and Depetris P J 2005 Mud and Mudstones: Introduction and Overview; Springer-Verlag, Heidelberg, 297p.

Rahman M J J and Suzuki S 2007 Geochemistry of sandstones from the Miocene Surma Group, Bengal basin, Bangladesh: Implications for provenance, tectonic setting and weathering; Geochem. J. 41 415-428.

Rajesham T, Bhaskar Rao Y J and Murti K S 1993 The Karimnagar granulite terrain - a new sapphirine bearing granulite province, south India; J. Geol. Soc. India 41 51-59.

Ramachandran A, Madhavaraju J, Ramasamy S, Lee Y I, Rao S, Chawngthu D L and Velmurugan K 2016 Geochemistry of the Proterozoic clastic rocks of Kerur Formation of Kaladgi-Badami Basin, Northern Karnataka, South India: Implications for paleoweathering and provenance; Turkish J. Earth Sci. 25 1503-1504.

Randive K R 2012 Elements of Geochemistry, Geochemical Exploration and Medical Geology; Research Publishing Services, Singapore, 454p.

Rao N K, Dora M L, Pophare A M, Malpe D B, Khuntia D B K, Meshram R R and Deshmukh M S 2017 Limestone Breccia from Gojoli Area, Eastern Flank of PranhitaGodavari Valley, Chandrapur District, Maharashtra; J. Geosci. Res. Spec. 1 235-239.

Roser B P 2000 Whole-rock geochemical studies of clastic sedimentary suites; Mem. Geol. Soc. Japan $\mathbf{5 7}$.

Roser B P and Korsch R J 1986 Determination of tectonic setting of sandstone-mudstone suites using $\mathrm{SiO}_{2}$ content and $\mathrm{K}_{2} \mathrm{O} / \mathrm{Na}_{2} \mathrm{O}$ ratio; J. Geol. 94 635-650.

Roser B P and Korsch R J 1988 Provenance signature of sandstone-mudstone suite determined using discriminant function analysis of major element data; Chem. Geol. 67 119-139.

Roser B P, Cooper R A, Nathan S A and Tulloch A J 1996 Reconnaissance sandstone geochemistry, provenance, and tectonic setting of the lower Paleozoic terrains of the West Coast and Nelson, New Zealand; New Zealand J. Geol. Geophys. 39 1-16.

Saeed E N, Barzi H M, Armstrong-Altrin and John S 2011 Petrography and geochemistry of clastic sedimentary rocks as evidences for provenance of the Lower Cambrian Lalun Formation, Posht-e-badam block, central Iran; J. African Earth Sci. 61(2) 142-159, https://doi.org/10. 1016/j.jafrearsci.2011.06.003.

Saha D and Deb S P 2014 Proterozoic evolution of Eastern Dharwar and Bastar cratons, India - An overview of the intracratonic basins, craton margins and mobile belts; J. Asian Earth Sci. 91 230-251.

Saha D and Ghosh G 1998 Lithostratigraphy of deformed Proterozoic rocks from around the confluence of the Godavari and Indrāvati Rivers, south India; Indian J. Geol. 70(3) 217-230.

Saha D and Chaudhuri A K 2003 Deformation of the Proterozoic successions in the Pranhita-Godavari Basin, South India - regional perspective; J. Asian Earth Sci. 21 $557-565$.

Santosh M, Yokoyama K and Acharyya S K 2004 Geochronology and tectonic evolution of Karimnagar and Bhopalpatnam granulite belts, Central India; Gondwana Res. 7 501-518.

Sari A and Koca D 2012 An approach to provenance, tectonic and redox conditions of Jurassic-Cretaceous Akkuyu Formation, Central Taurids, Turkey; Min. Res. Exp. Bull. 144 51-74.

Sharma A, Sensarma S, Kamlesh K, Khanna P P and Saini N K 2013 Mineralogy and geochemistry of the Mahi River sediments in tectonically active western India: Implications for Deccan large igneous province source, weathering and mobility of elements in a semi-arid climate; Geochim. Cosmochim. Acta 104 63-83. 
Sashidharan K 2007 Petrology and geochemistry of Mul granite pluton, Western Bastar Craton, Chandrapur District, Maharashtra; Gondwana Geol. Mag. 10 45-54.

Sashidharan K and Ganvir D V 2000 Geological Report of Gondpipri, GSI Portal.

Shadan M and Hosseini-Barzi M 2013 Petrography and geochemistry of the Ab-e-Haji Formation in central Iran: Implications for provenance and tectonic setting in the southern part of the Tabas block; Rev. Mex. Cienc. Geol. 30 80-95.

Sreenivasa Rao T 1987 The Pakhal Basin - a perspective; In: Purana Basins of Peninsular India (ed.) Radhakrishna B P, Geol. Soc., India Memoir 6 161-187.

Srinivasa Rao K, Sreenivasa Rao T and Rajagopalan Nair S 1979 Stratigraphy of the upper Precambrian Albaka belt, East Godavari River in AP and MP; J. Geol. Soc. India 20 205-213.

Srivastava A K, Randive K R and Khare N 2013 Mineralogical and geochemical studies of glacial sediments from Schirmacher Oasis, East Antarctica; Quat. Int. 292 205216.

Sun L, Gui H and Chen S 2012 Geochemistry of sandstones from the Neoproterozoic Shijia Formation, northern Anhui Province, China: Implications for provenance, weathering and tectonic setting; Chem. Erde 72 253-260.

Sun S and McDonough W F 1989 Chemical and isotopic systematics of oceanic basalts: Implications for mantle composition and processes; Geol. Soc. London, Spec. Publ. 42 313-345, https://doi.org/10.1144/GSL.SP.1989. 042.01.19.

Tao H, Wang Q, Yang X and Jiang L 2013 Provenance and tectonic setting of Late Carboniferous clastic rocks in west Junggar, Xinjiang, China: A case from the Halaalat Mountains; J. Asian Earth Sci. 64 210-222.

Tawfik H A, Salah M K, Maejima W, Armstrong-Altrin J S 2017 Petrography and geochemistry of the Lower Miocene
Moghra sandstones, Qattara Depression, north Western Desert, Egypt; Geol. J. 154(1) 1-23.

Taylor S R and McLennan S M 1985 The Continental Crust: Its Composition and Evolution. Oxford, Blackwell, 349p.

Van de Kamp P C and Leake B E 1985 Petrography and geochemistry of feldspathic and mafic sediments of the northeastern Pacific margin; Trans. Roy. Soc. Edinburgh Earth Sci. $\mathbf{7 6}$ 411-449.

Vdacny M, Vozárová A and Vozár J 2013 Geochemistry of the Permian sandstones from the Malužiná Formation in the MaléKarpatyMts (Hronic Unit, Western Carpathians, Slovakia): Implications for source-area weathering, provenance and tectonic setting; Geol. Carpath. 6423 38.

Verma S P and Armstrong-Altrin J S 2013 New multidimensional diagrams for tectonic discrimination of silica clastic sediments and their application to Pre-Cambrian basins; Chem. Geol. 355 117-180.

Yerino L N and Maynard J B 1984 Petrography of modern marine sands from the Peru-Chile Trench and adjacent areas; Sedimentology 31 83-89.

Zaid S M 2012 Provenance, diagenesis, tectonic setting and geochemistry of Rudies sandstone (Lower Miocene), Warda Field, Gulf of Suez, Egypt; J. Afr. Earth Sci. 66$6756-71$.

Zaid S M 2013 Provenance, diagenesis, tectonic setting and reservoir quality of the sandstones of the Kareem Formation, Gulf of Suez, Egypt; J. Afr. Earth Sci. 85 31-52.

Zaid S M 2015 Geochemistry of sandstones from the Pliocene Gabir Formation, north Marsa Alam, Red Sea, Egypt: Implication for provenance, weathering and tectonic setting; J. Afr. Earth Sci. 102 1-17.

Zaid S M 2017 Petrography and geochemistry of the Middle Miocene Gebel El Rusas sandstones, Eastern Desert, Egypt: Implications for provenance and tectonic setting; J. Earth Syst. Sci. 126 1-22. 